\title{
Thermal alteration of soil physico-chemical properties: a systematic study to infer response of Sierra Nevada climosequence soils to forest fires
}

\author{
Samuel N. Araya ${ }^{1}$, Mercer Meding ${ }^{2}$, and Asmeret Asefaw Berhe ${ }^{1,3}$ \\ ${ }^{1}$ Environmental Systems Graduate Group, University of California, Merced, CA, USA \\ ${ }^{2}$ Soil, Water, and Environmental Science Department, University of Arizona, Tucson, AZ, USA \\ ${ }^{3}$ Life and Environmental Sciences Unit, University of California, Merced, CA, USA \\ Correspondence to: Samuel N. Araya (saraya@ucmerced.edu)
}

Received: 25 January 2016 - Published in SOIL Discuss.: 1 February 2016

Revised: 4 June 2016 - Accepted: 6 July 2016 - Published: 22 July 2016

\begin{abstract}
Fire is a common ecosystem perturbation that affects many soil properties. As global fire regimes continue to change with climate change, we investigated thermal alteration of soils' physical and chemical properties after they are exposed to a range of temperatures that are expected during prescribed and wildland fires. For this study, we used topsoils collected from a climosequence transect along the western slope of the Sierra Nevada that spans from 210 to $2865 \mathrm{~m}$ a.s.l. All the soils we studied were formed on a granitic parent material and had significant differences in soil organic matter (SOM) concentration and mineralogy owing to the effects of climate on soil development. Topsoils $(0-5 \mathrm{~cm}$ depth) from the Sierra Nevada climosequence were heated in a muffle furnace at six set temperatures that cover the range of major fire intensity classes $(150,250,350$, 450,550 and $650^{\circ} \mathrm{C}$ ). We determined the effects of heating temperature on soil aggregate strength, aggregate size distribution, specific surface area (SSA), mineralogy, $\mathrm{pH}$, cation exchange capacity (CEC), and carbon (C) and nitrogen $(\mathrm{N})$ concentrations. With increasing temperature, we found significant reduction of total $\mathrm{C}, \mathrm{N}$ and CEC. Aggregate strength also decreased with further implications for loss of $\mathrm{C}$ protected inside aggregates. Soil $\mathrm{pH}$ and SSA increased with temperature. Most of the statistically significant changes $(p<0.05)$ occurred between 350 and $450^{\circ} \mathrm{C}$. We observed relatively smaller changes at temperature ranges below $250^{\circ} \mathrm{C}$. This study identifies critical temperature thresholds for significant physico-chemical changes in soils that developed under different climate regimes. Our findings will be of interest to studies of inferences for how soils are likely to respond to different fire intensities under anticipated climate change scenarios.
\end{abstract}

\section{Introduction}

Fire is a common, widespread phenomenon in many ecosystems around the world (Bowman et al., 2009). Vegetation fires burn an estimated 300 to 400 million hectares of land globally every year (FAO, 2005). In the US alone, over 80000 fires were reported in 2014, including about 63000 wildland fires, and 17000 prescribed burns that burned over 1.5 million and 970000 ha of land, respectively (National Interagency Fire Center, 2015). Climate and climatic variations exert strong control on the distribution, frequency, and severity of fires (Harrison et al., 2010). Signif- icant changes in global fire regimes are anticipated because of climate change including an increase in frequency of fires in the coming decades (Pechony and Shindell, 2010; Westerling et al., 2006). However, our understanding of how climate change and changes in fire regimes will interact to influence topsoils in fire affected ecosystems is limited.

Even though humans are responsible for causing a substantial proportion of vegetation fires (Caldararo, 2002), vegetation fires are also natural phenomena with an important role in maintaining the health of many ecosystems around the world (Harrison et al., 2010). In the Sierra Nevada, veg- 


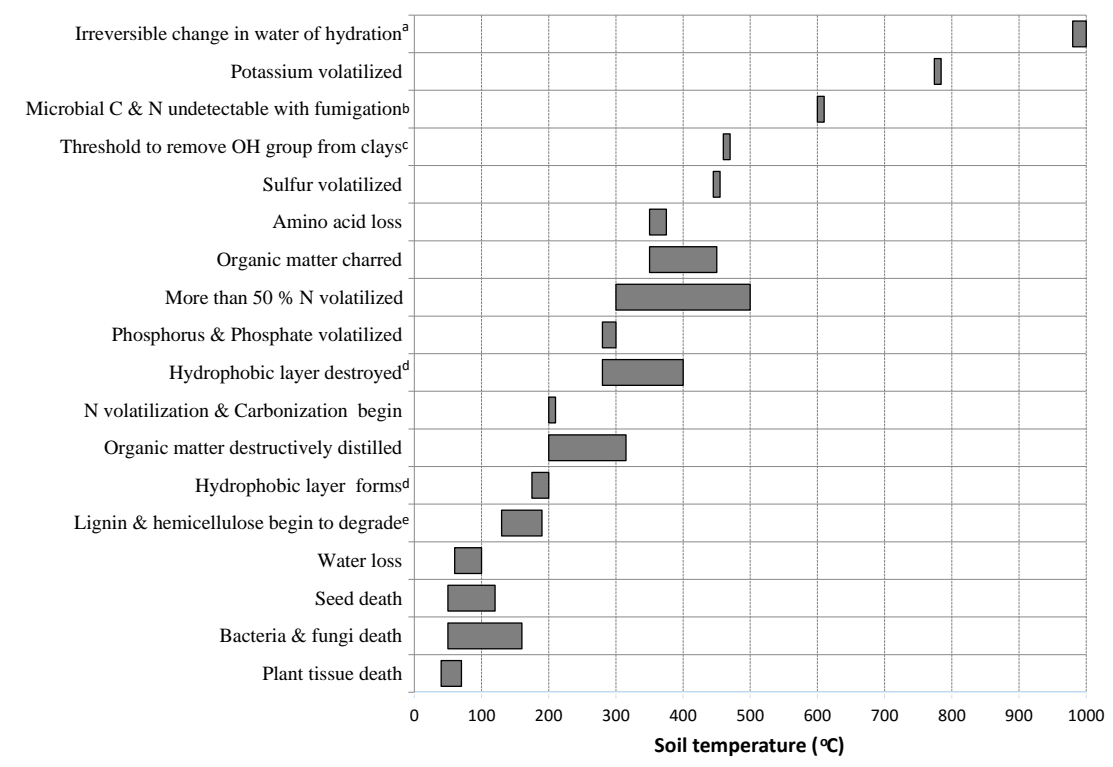

Figure 1. Temperature thresholds and ranges associated with fire heating. Figure adopted and expanded from Massman et al. (2010) $\left({ }^{\mathrm{a}}\right.$ DeBano et al., 1977; ${ }^{\mathrm{b}}$ Diaz-Ravina et al., 1992; ${ }^{\mathrm{c}}$ Giovannini et al., 1988; ${ }^{\mathrm{d}}$ DeBano, 2000 and ${ }^{\mathrm{e}}$ Knicker, 2007).

etation fires have a major influence on the landscapes (McKelvey et al., 1996).

In addition to alteration of vegetation, fire also significantly affects the physical, chemical and biological properties of soils (Certini, 2005; González-Pérez et al., 2004; Mataix-Solera et al., 2011). The degree of alteration caused by fires depends on the fire intensity and duration, which in turn depend on factors such as the amount and type of fuels, properties of above ground biomass, air temperature and humidity, wind, topography, and soil properties such as moisture content, texture and soil organic matter (SOM) content (DeBano et al., 1998). The first-order effects of fire on soil are caused by the input of heat causing extreme soil temperatures in topsoil (Badía and Martí, 2003b; Neary et al., 1999) resulting in loss and transformation of SOM, changes in soil hydrophobicity, changes in soil aggregation, loss of soil mass, and addition of charred material and other combustion products (Albalasmeh et al., 2013; Mataix-Solera et al., 2011; Rein et al., 2008). Soil temperature thresholds for some important soil transformations are illustrated in Fig. 1.

The duration of burning impacts soil properties because it determines the amount of energy transferred through the soil. Fires with a longer duration typically have a greater impact on soil properties and SOM than higher temperature fires if they are fast-moving (Frandsen and Ryan, 1986; González-Pérez et al., 2004). Fires also impact soil by altering and removing above-ground vegetation and topsoil biomass, and increasing soil erodibility (Carroll et al., 2007; DeBano, 1991), subsequently leading to a shift in plant and microbial populations (Janzen and Tobin-Janzen, 2008).

The aim of this study is to investigate effects of heating temperatures on important soil properties. Here we aim to determine how the same input of energy from fires affects topsoils that vary significantly based on carbon content, mineralogy, and associated soil physical and chemical properties. The inferences derived from this work are essential for determining how changing climate regimes (and associated changes in vegetation dynamics and soil properties) are likely to influence the response of topsoil to wild and prescribed fires. We use a laboratory heating experiment on soils from a well-characterized climosequence in the western Sierra Nevada mountain range to determine: (1) magnitudes of change in soil physico-chemical properties associated with different fire heating temperatures; (2) identify critical thresholds for major changes in soil-physico-chemical properties for soils that significantly vary based on organic matter properties, texture, mineralogy, and other properties; and (3) infer the implications of changing climate on topsoil physico-chemical properties that might experience changing fire regime. This study aims to contribute to the systematic evaluation and development of ability to predict the effect of different intensity fires on soil properties under changing climate scenarios.

\section{Materials and methods}

\subsection{Study site and soil description}

For this study, we collected soils from five sites across an elevation transect along the western slope of the central Sierra Nevada (Fig. 2); the sites were previously characterized by Dahlgren et al. (1997). We selected four forested sites that are likely to experience forest fires and a fifth lower elevation grassland site for comparison. 
Table 1. Soil classification and site description for the five sites along elevational transect in the western slopes of the Sierra Nevada (adapted from Dahlgren et al., 1997).

\begin{tabular}{|c|c|c|c|c|c|c|c|}
\hline $\begin{array}{l}\text { Soil } \\
\text { series }\end{array}$ & $\begin{array}{r}\text { Elevation } \\
(\mathrm{m})\end{array}$ & Ecosystem & $\begin{array}{r}\mathrm{MAT}^{\mathrm{a}} \\
\left({ }^{\circ} \mathrm{C}\right)\end{array}$ & $\begin{array}{r}\mathrm{MAP}^{\mathrm{b}} \\
(\mathrm{cm})\end{array}$ & Precip $^{c}$ & $\begin{array}{l}\text { Dominant vegetation (listed } \\
\text { in order of dominance) }\end{array}$ & Soil taxonomy (family) \\
\hline Vista & 210 & $\begin{array}{l}\text { Oak } \\
\text { woodland }\end{array}$ & 16.7 & 33 & Rain & $\begin{array}{l}\text { Annual grasses; Quercus } \\
\text { douglasii; Quercus } \\
\text { wislizeni }\end{array}$ & $\begin{array}{l}\text { Coarse-loamy, mixed, } \\
\text { superactive, thermic; } \\
\text { Typic Haploxerepts }\end{array}$ \\
\hline Musick & 1384 & $\begin{array}{l}\text { Oak/mixed- } \\
\text { conifer } \\
\text { forest }\end{array}$ & 11.1 & 91 & Rain & $\begin{array}{l}\text { Pinus ponderosa; } \\
\text { Calocedrus decurrens; } \\
\text { Quercus kelloggii; } \\
\text { Chamaebatia foliolosa }\end{array}$ & $\begin{array}{l}\text { Fine-loamy, mixed, } \\
\text { semiactive, mesic; } \\
\text { Ultic Haploxeralf }\end{array}$ \\
\hline Shaver & 1737 & $\begin{array}{l}\text { Mixed- } \\
\text { conifer } \\
\text { forest }\end{array}$ & 9.1 & 101 & Snow & $\begin{array}{l}\text { Abies concolor; Pinus } \\
\text { lambertiana; Pinus } \\
\text { ponderosa; Calocedrus } \\
\text { decurrens }\end{array}$ & $\begin{array}{l}\text { Coarse-loamy, mixed, } \\
\text { superactive, mesic; } \\
\text { Humic Dystroxerepts }\end{array}$ \\
\hline Sirretta & 2317 & $\begin{array}{l}\text { Mixed- } \\
\text { conifer } \\
\text { forest }\end{array}$ & 7.2 & 108 & Snow & $\begin{array}{l}\text { Pinus jeffreyi; Abies } \\
\text { magnifica; Abies } \\
\text { concolor }\end{array}$ & $\begin{array}{l}\text { Sandy-skeletal, mixed, } \\
\text { frigid; Dystric } \\
\text { Xerorthent }\end{array}$ \\
\hline Chiquito $^{\mathrm{d}}$ & 2865 & $\begin{array}{l}\text { Subalpine } \\
\text { mixed- } \\
\text { conifer } \\
\text { forest }\end{array}$ & 3.9 & 127 & Snow & $\begin{array}{l}\text { Pinus contorta } \\
\text { murrayana; Pinus } \\
\text { monticola; Lupinus } \\
\text { species }\end{array}$ & $\begin{array}{l}\text { Sandy-skeletal, mixed; } \\
\text { Entic Cryumbrept }\end{array}$ \\
\hline
\end{tabular}

\footnotetext{
${ }^{a}$ Mean annual air temperature, calculated from regression equation of Harradine and Jenny (1958); ${ }^{b}$ mean annual precipitation; ${ }^{c}$ dominant form of precipitation;

$\mathrm{d}$ tentative soil series.
}

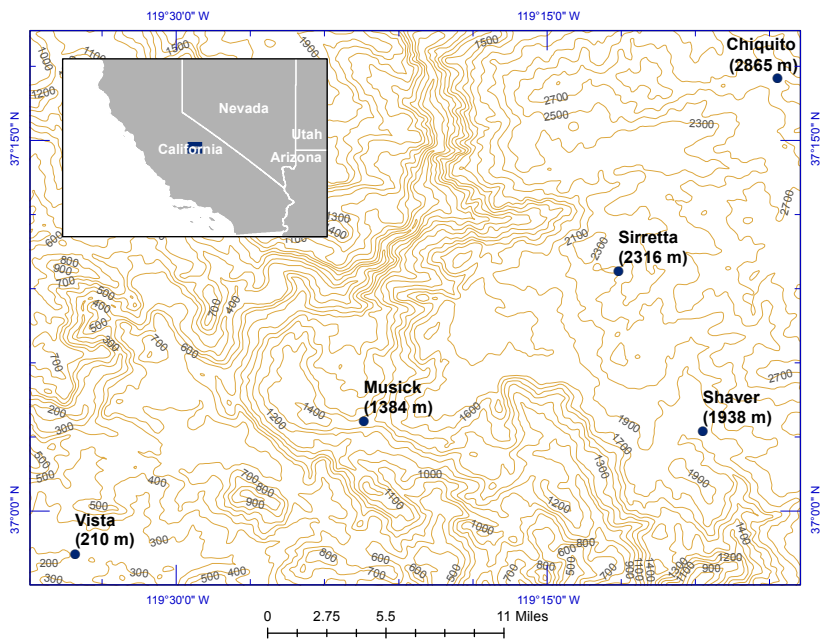

Figure 2. Map of the five sampling sites along elevational transect in the western Sierra Nevada, California (Base map from US Geological Survey, 2015).

All the sites have a Mediterranean climate characterized by warm to hot dry summers and cool to cold wet winters. Mean annual air temperature ranges from $16.7^{\circ} \mathrm{C}$ at the lowest site located at $210 \mathrm{~m}$ to $3.9^{\circ} \mathrm{C}$ at the highest elevation site which is at an elevation of $2865 \mathrm{~m}$. Annual precipitation ranges from $33 \mathrm{~cm}$ at the lowest site to $127 \mathrm{~cm}$ at the highest site (Dahlgren et al., 1997; Rasmussen et al., 2007) (Table 1).

The lower elevation woodlands of Sierra Nevada experience less frequent fires than further upslope and the fires are often fast moving and lower severity (Skinner and Chang, 1996). At the middle-elevation zone of the Sierran forest, the mixed-conifer zones, frequent fires are low to moderate severity at lower altitudes but fire frequency generally increases with altitude towards the upper elevation of the mixed conifer forest (Caprio and Swetnam, 1995). Fires are infrequent and have a low severity within the high altitude, subalpine zone of Sierra (Skinner and Chang, 1996).

Soils from the lowest elevation site, Vista soils (210 ma.s.1.), fall within the oak woodland zone (elevations $<1008 \mathrm{~m}$ ). This is the only soil in our study that does not have an O-horizon, the soil has dense annual grass cover, however, and the A-horizon SOM originates mainly from root turnover. Musick soils (1384 ma.s.l.) lie within oak/mixed-conifer forest (1008-1580 ma.s.l.) and mixedconifer forest (1580-2626 m a.s.l.). These soils receive the highest biomass and litter fall. Shaver and Sirretta soils (2317 $\mathrm{m}$ a.s.1.) fall within the mixed-conifer forest range zone while Chiquito soils ( $2865 \mathrm{~m}$ a.s.l.) lies within the subalpine mixed-conifer forest range (2626-3200 m a.s.l.). These soils have lower biomass and litter fall compared to the lower elevation soils (van Wagtendonk and Fites-Kaufman, 2006). 
Table 2. Bulk density, water content, $\mathrm{pH}, \mathrm{C}$ concentration, cation exchange capacity (CEC), specific surface area (SSA) and particle size distribution for the five soils (mean \pm standard error, $n=3$ ).

\begin{tabular}{|c|c|c|c|c|c|c|c|c|c|}
\hline \multirow[t]{2}{*}{$\begin{array}{l}\text { Soil series and } \\
\text { elevation }(m)\end{array}$} & \multirow{2}{*}{$\begin{array}{c}\text { Bulk } \\
\text { density } \\
\left(\mathrm{g} \mathrm{cm}^{-3}\right)\end{array}$} & \multirow{2}{*}{$\begin{array}{c}\text { Gravimetric } \\
\text { water } \\
\text { content } \\
(\%)\end{array}$} & \multirow[t]{2}{*}{$\begin{array}{c}\mathrm{pH} \\
\left(\mathrm{CaCl}_{2}\right)\end{array}$} & \multirow[t]{2}{*}{$\begin{array}{c}\text { Carbon } \\
(\%)\end{array}$} & \multirow[t]{2}{*}{$\begin{array}{l}\mathrm{CEC} \\
\left(\mathrm{cmol}_{\mathrm{c}} \mathrm{kg}^{-1}\right)\end{array}$} & \multirow[t]{2}{*}{$\begin{array}{l}\text { SSA } \\
\left(\mathrm{m}^{2} \mathrm{~g}^{-1}\right)\end{array}$} & \multicolumn{3}{|c|}{$\begin{array}{c}\text { Particle size } \\
\text { distribution* }(\%)\end{array}$} \\
\hline & & & & & & & Sand & Silt & Clay \\
\hline Vista (210) & $1.26 \pm 0.07$ & $0.7 \pm 0.0$ & $5.53 \pm 0.0$ & $1.51 \pm 0.2$ & $8.40 \pm 1.1$ & $1.75 \pm 0.2$ & 79 & 11 & 10 \\
\hline Musick (1384) & $0.90 \pm 0.06$ & $9.3 \pm 1.6$ & $4.67 \pm 0.1$ & $7.66 \pm 0.8$ & $25.20 \pm 2.0$ & $4.98 \pm 0.3$ & 60 & 27 & 15 \\
\hline Shaver (1737) & $0.98 \pm 0.06$ & $8.3 \pm 1.1$ & $4.85 \pm 0.3$ & $2.84 \pm 0.2$ & $10.67 \pm 2.1$ & $3.08 \pm 0.3$ & 80 & 15 & 5 \\
\hline Sirretta (2317) & $0.61 \pm 0.09$ & $9.9 \pm 2.2$ & $4.54 \pm 0.1$ & $4.74 \pm 0.8$ & $12.23 \pm 2.6$ & $6.63 \pm 0.8$ & 80 & 15 & 5 \\
\hline Chiquito (2865) & $1.17 \pm 0.03$ & $6.1 \pm 1.9$ & $3.96 \pm 0.1$ & $4.10 \pm 0.2$ & $6.03 \pm 1.8$ & $1.00 \pm 0.04$ & 80 & 16 & 4 \\
\hline
\end{tabular}

* Particle size distribution of topsoil profile from Dahlgren et al. (1997): Vista (0-14 cm), Musick (0-29 cm), Shaver (0-4 cm), Sirretta (0-6 cm) and Chiquito (0-6 cm).

The western slope of central Sierra Nevada presents a remarkable climosequence of soils that developed under similar granitic parent material and are located in landscapes of similar age, relief, slope and aspect (Trumbore et al., 1996) with significant developmental differences attributed to climate. The soils at mid-elevation range (1000 to $2000 \mathrm{~m}$ a.s.l.) tend to be highly weathered while soils at high and low elevations are relatively less developed (Dahlgren et al., 1997; Harradine and Jenny, 1958; Huntington, 1954; Jenny et al., 1949). Among the most important changes in soil properties along the climosequence include changes in soil organic carbon (SOC) concentration, base saturation, and mineral desilication and hydroxyl-Al interlayering of $2: 1$ layer silicates. Soil $\mathrm{pH}$ generally decreases with elevation and the concentrations of clay and secondary iron oxides show a step change at the elevation of present-day average effective winter snowline, i.e. $1600 \mathrm{~m}$ elevation (Tables 1 and 2) (California Department of Water Resources, 1952-1962; Dahlgren et al., 1997).

\subsection{Experimental design and sample collection}

To investigate the effect of heating temperature on physicochemical properties of soils with significantly different carbon contents, mineralogy, and overall development, we collected top soils ( 0 to $5 \mathrm{~cm}$ depth) from five sites. Triplicate samples, approximately $10 \mathrm{~m}$ apart, were collected from each site. The soils were air-dried at room temperature and passed through a $2 \mathrm{~mm}$ sieve. Prior to furnace heating, the soils were oven dried at $60^{\circ} \mathrm{C}$ overnight. Soil bulk density and field soil moisture were determined from separate undisturbed core samples collected from each site (Table 2).

Sub-samples from each soil were heated in muffle furnace to one of six selected maximum temperatures $(150,250,350$, 450,550 and $650^{\circ} \mathrm{C}$ ). To ensure uniform soil heating and reduce formation of heating gradient inside, the soils were packed $1 \mathrm{~cm}$ high in a $7 \mathrm{~cm}$ diameter porcelain flat capsule crucibles. Oxygen supply during the heating was only limited by the availability of space, the furnace was not sealed and the volume of soil sample to volume of air in furnace was approximately $1: 50$. Furnace temperature was ramped up at a rate of $3{ }^{\circ} \mathrm{C} \mathrm{min}^{-1}$ and soils were exposed to the maximum temperature for $30 \mathrm{~min}$. Once cooled to touch, soils were stored in air-tight polyethylene bags prior to analysis.

The six heating temperatures were selected to correspond with fire intensity categories that are based on maximum surface temperature (DeBano et al., 1977; Janzen and TobinJanzen, 2008; Neary et al., 1999), that is, low intensity $\left(150\right.$ and $\left.250^{\circ} \mathrm{C}\right)$, medium intensity $\left(350\right.$ and $\left.450^{\circ} \mathrm{C}\right)$, and high intensity $\left(550\right.$ and $\left.650^{\circ} \mathrm{C}\right)$. These fire intensity classes generally correspond with thresholds for important thermal reactions in soils observed by differential thermal analyses (Giovannini et al., 1988; Soto et al., 1991; Varela et al., 2010). A heating rate of $3{ }^{\circ} \mathrm{C} \mathrm{min}^{-1}$ is preferred in laboratory fire simulation experiments (Giovannini et al., 1988; Terefe et al., 2008; Varela et al., 2010), the slow heating rate prevents sudden combustion when soil's ignition temperature is reached at about $220^{\circ} \mathrm{C}$ (Fernández et al., 1997, 2001; Varela et al., 2010). The samples were exposed to the maximum set temperature for a period of $30 \mathrm{~min}$. This length of time ensures that the entire sample is uniformly heated at the set temperature and is in keeping with a wide majority of similar laboratory soil heating experiments (for example Badía and Martí, 2003a; Fernández et al., 2001; Giovannini, 1994; Varela et al., 2010; Zavala et al., 2010). The duration of soil heating under vegetation fires is highly varied and not uniform across landscape (Parsons et al., 2010). The same heating procedure was used for all the soils so that it would be possible to compare how the soils from different climate regimes are likely to respond to the fires.

\subsection{Laboratory analysis}

Soil color was measured using the Munsell Color Charts. Dry color was measured from air-dried samples and moisture was added to same sample for moist color measurement. Dry-aggregate size distribution was measured by sieving. Samples were dry sieved into three aggregate 
size classes: $2-0.25 \mathrm{~mm}$ (macro-aggregates), $0.25-0.053 \mathrm{~mm}$ (micro-aggregates) and $<0.053 \mathrm{~mm}$ (silt and clay-sized particles). These aggregate size classes were selected to enable comparison with other studies that investigated the effect of different natural and anthropogenic properties on soil aggregate dynamics and aggregate protected organic matter (Six et al., 2000).

Water-stable aggregate percent was measured by wetsieving methods of Nimmo and Perkins (2002). For this procedure, a wet-sieving apparatus with $0.25 \mathrm{~mm}$ mesh size sieve is used (Eijkelkamp Agrisearch Equipment, Giesbeek, The Netherlands). Four grams of soil sample was placed into a sieve and pre-wetted slowly from a moist tissue paper placed beneath the sieve. The soil sample was then wetsieved with an up-down motion at a rate of 35 cycles per minute and a vertical distance of $1.3 \mathrm{~cm}$. Mass of the soil passing through the sieve was recorded $\left(M_{1}\right)$ after evaporating the supernatant water in oven. The remaining soil sample was subjected to a second round of wet-sieving using a dispersing solution $\left(2 \mathrm{~g} \mathrm{~L}^{-1}\right.$ of sodium hexametaphosphate for the soils with $\mathrm{pH}>7$ and $2 \mathrm{~g} \mathrm{~L}^{-1} \mathrm{NaOH}$ for the soils with $\mathrm{pH}<7$ ) until all particles that were smaller than the sieve screen opening pass. Mass of the soil that passed through the sieve in the second round of sieving $\left(M_{2}\right)$ was also determined by evaporating supernatant solution in oven and subtracting the weight of the dispersing-agent. The water-stable aggregate (WSA) fraction was calculated as:

$\mathrm{WSA}=\frac{M_{2}}{M_{1}+M_{2}} \times 100 \%$.

Specific surface area was measured using automated $\mathrm{N}_{2}$-BET analyzer (Micromeritics Tri-Star 3000, Micromeritics Instrument Corporation, Norcross, GA, USA). For this procedure, approximately $1 \mathrm{~g}$ of soil was oven dried at $60^{\circ} \mathrm{C}$ for $36 \mathrm{~h}$ and out-gassed for another $30 \mathrm{~min}$ using a flow of $\mathrm{N}_{2}$ gas with outgassing station mantle set to a temperature of $105^{\circ} \mathrm{C}$. Measurement was done using ultra-high purity $\mathrm{N}_{2}$ gas and the instrument was set to use seven-point $\mathrm{N}_{2}$-BET adsorption isotherm measurement from which the Micromeritics software calculated specific surface area.

Soil mineralogy was measured using X-ray diffraction analysis (XRD) using PANalytical Xpert Pro diffractometer (PANalytical Inc., Westborough, MA, USA). We used the PANalytical Xpert Pro software for identification of mineral phases and Rietveld refinement for quantification (Rietveld, 1969; Schulze and Dixon, 2002). Soil samples were ground to a fine powder consistency using a ball-mill (8000M MiXer/Mill, with $65 \mathrm{~mL}$ stainless steel grinding vial set, SPEX SamplePrep, LLC, Metuchen, NJ, USA) and oven dried at $60^{\circ} \mathrm{C}$ for over $36 \mathrm{~h}$. Samples were scanned at generator setting of $45 \mathrm{~mA}$ by $40 \mathrm{kV}$. Scan start position was set to $5^{\circ} 2 \theta$ and end position was set to $1202 \theta$. Scan step time was set to $10 \mathrm{~s}$ with a step interval size of $0.0170^{\circ} 2 \theta$. At least two replicate measurements were run for each sample and samples were measured in random order.
Soil $\mathrm{pH}$ was measured using $1: 2$ solid : solution ratio mixtures in a deionized water and $0.01 \mathrm{MCaCl}_{2}$ solution. Five grams of soil was mixed by shaking with $10 \mathrm{~mL}$ of solution and allowed to stand for $30 \mathrm{~min}$, stirring every $10 \mathrm{~min}$. The $\mathrm{pH}$ reading was taken by placing electrodes directly in the sediment slurry immediately after stirring (Thomas, 1996).

Cation exchange capacity (CEC) was measured by the barium exchange method. Barium was used to quantitatively displace soil exchangeable cations, and excess barium was removed by four deionized water rinses. A known quantity of calcium is then exchanged for barium and excess solution calcium is measured in order to determine CEC by the difference in the quantity of the calcium added and the amount left in the resulting solution. The method has a detection limit of $2.0 \mathrm{cmol}_{\mathrm{c}} \mathrm{kg}^{-1}$ (Rible and Quick, 1960).

Elemental concentrations of carbon (C) and nitrogen (N) were measured using an elemental combustion system (Costech ECS 4010 CHNSO Analyzer, Costech Analytical Technologies, Valencia, CA, USA) that is interfaced with a mass spectrometer (DELTA V Plus Isotope Ratio Mass Spectrometer, Thermo Fisher Scientific, Inc, Waltham, MA, USA). For the analyses, the soil samples were ground to a powder consistency using a ball-mill (8000M MiXer/Mill, with a $55 \mathrm{~mL}$ tungsten Carbide Vial, SPEX SamplePrep, LLC, Metuchen, NJ, USA) and oven-dried at $60^{\circ} \mathrm{C}$ for over $36 \mathrm{~h}$. This lower temperature and longer duration ovendrying was used to avoid possible heating related $\mathrm{C}$ or $\mathrm{N}$ changes that might occur if drying was done at $105^{\circ} \mathrm{C}$ (Kaiser et al., 2015). The $\mathrm{C}$ and $\mathrm{N}$ concentration results were corrected for moisture by oven-drying subsamples at $105^{\circ} \mathrm{C}$ overnight and to determine moisture content. The $\mathrm{C}$ and $\mathrm{N}$ concentration results were corrected by adjusting for moisture as: $W_{\text {adj }}=W \times\left(100-W_{\mathrm{m}}\right)$. Where $W_{\text {adj }}$ is the adjusted percent concentration, $W$ is the concentration before moisture adjustment and $W_{\mathrm{m}}$ is the percent moisture content. All concentration changes resulting from moisture adjustment were a decrease of less than $1 \%$ of the value.

\subsection{Statistical analysis}

All quantitative results are expressed as means of three replicates \pm standard error, unless otherwise indicated. Differences of means were tested by Analysis of Variance (ANOVA) and pairwise comparison of treatments done using Tukey's HSD test at $p<0.05$ significance level. The normality of the data and the homogeneity of variances was checked using Shapiro-Wilk's and Levene's tests respectively. All statistical analyses were performed using R statistical software (R Core Team, 2014). ANOVA was implemented using aov function and Tukey's HSD test subsequently implemented on the (aov) fit by TukeyHSD function. The ANOVA tables and Tukey's HSD comparison of means tables are given in the Supplement. The ordinary linear regression technique was used to examine relationships between soil properties. 

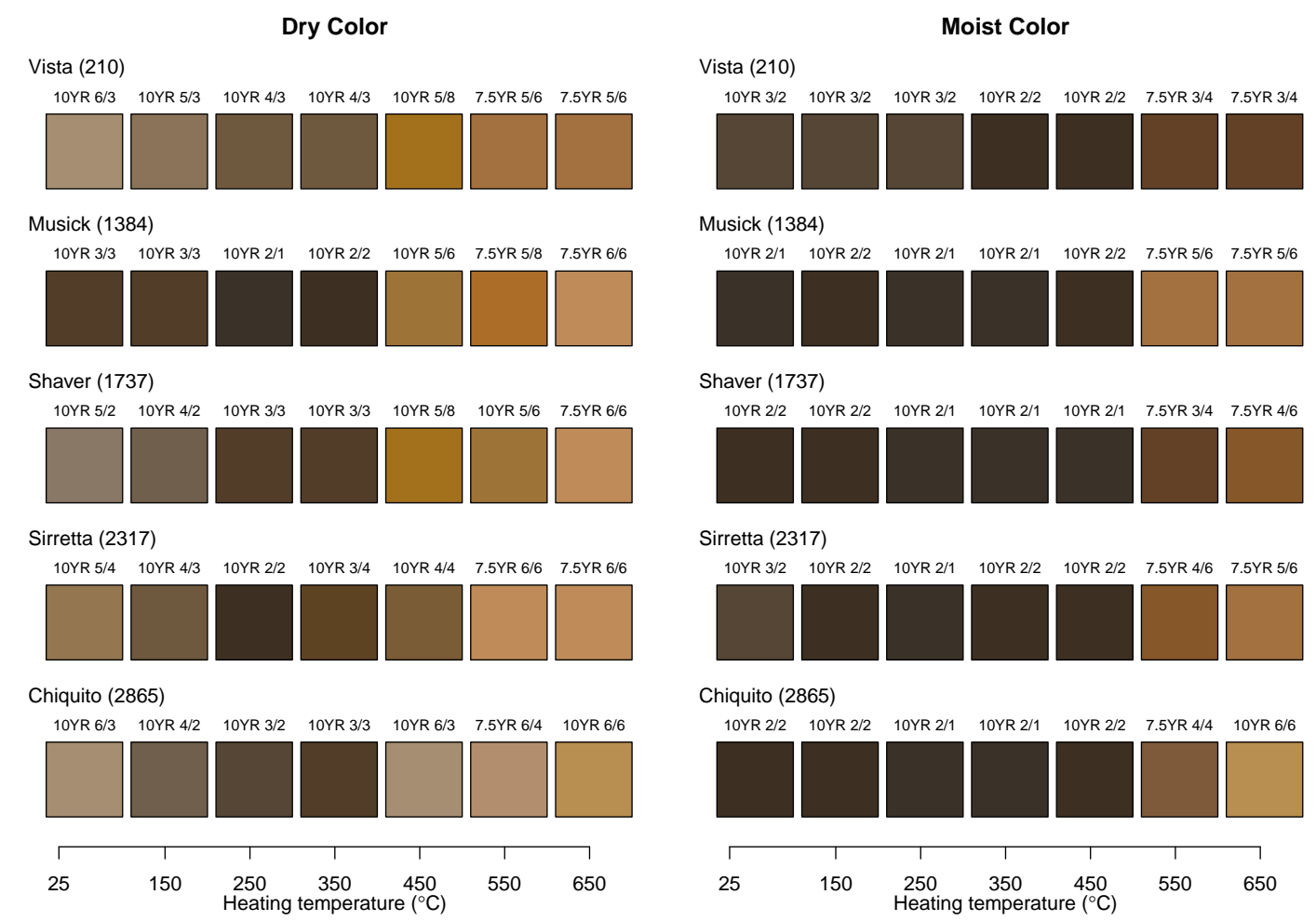

Figure 3. Soil color change across heating temperatures. Colors produced from CIExyY colorspace equivalents to Munsell colors (Munsell Color Science Laboratory, 2015). CIExyY colors were converted to RGB system (Rossel et al., 2006; UC Davis Soil Resource Laboratory, 2015) and visually compared with Munsell Soil Color book for plotting.

\section{Results}

\subsection{Soil color}

We observed a marked soil color change, as inferred using the Munsell color system, with increasing heating temperature (Fig. 3). As the heating temperatures increased, the soils initially got darker, reaching their darkest color at midtemperatures $\left(250-350^{\circ} \mathrm{C}\right.$ when measured in dry soil, and $250-450{ }^{\circ} \mathrm{C}$ when soils were moist). At higher temperatures, the soils became markedly lighter and became increasingly reddish in color (with hue changing from 10YR to 7.5YR at temperatures above $550^{\circ} \mathrm{C}$ ). Color change patterns were similar for both, dry and moist soil measurements except for the marked color change occurring at $450{ }^{\circ} \mathrm{C}$ when dry and at $550^{\circ} \mathrm{C}$ when moist. Across the heating temperature range, Vista ( $210 \mathrm{~m}$ a.s.l.) soils showed the least pronounced increase in darkness at $350^{\circ} \mathrm{C}$ while Shaver $(1737 \mathrm{~m}$ a.s.l.) soils showed the most pronounced darkening at that temperature range (from dry color of 10YR 5/2 unburned to 10YR $3 / 3$ by $350^{\circ} \mathrm{C}$ ). At higher temperatures, Musick soils (1384 $\mathrm{m}$ a.s.l.) showed the largest change in dry soil color going from $10 \mathrm{YR} 2 / 2$ at $350{ }^{\circ} \mathrm{C}$ to $7.5 \mathrm{YR} 6 / 6$ at $650^{\circ} \mathrm{C}$.

\subsection{Mass loss}

Mass loss was proportional to heating temperature in all the soils. For the high and low elevation soils, statistically significant mass loss, compared to unburned soils, was observed above $350^{\circ} \mathrm{C}$. In contrast, significant mass loss was observed for the two mid-elevation soils of Musick (1384 m a.s.l.) and Shaver $\left(1737 \mathrm{~m}\right.$ a.s.l.) starting at $250^{\circ} \mathrm{C}$. There was no significant mass loss at temperatures above $450^{\circ} \mathrm{C}$ for all soils. For all our soils, the steepest mass loss was observed between temperatures of 250 and $450{ }^{\circ} \mathrm{C}$ (Fig. 4). Vista (210 m a.s.1.) soils showed the lowest mass loss with heating while $\mathrm{Mu}$ sick soils (1384 $\mathrm{m}$ a.s.l.) showed the highest mass loss with heating.

\subsection{Aggregate stability and size distribution}

Aggregate stability generally decreased with temperature for all soils. While aggregate stability decreased in an almost uniform manner with increase in temperature for the lower to mid elevation soils, the higher elevation Sirretta (2317 m a.s.1.) and Chiquito ( $2865 \mathrm{~m}$ a.s.1.) soils showed a stepwise decrease in aggregate stability at 250 and $350^{\circ} \mathrm{C}$ respectively. At higher heating temperatures aggregate stability for the two soils showed only a small decrease from these two temperatures. Statistically significant decrease in 


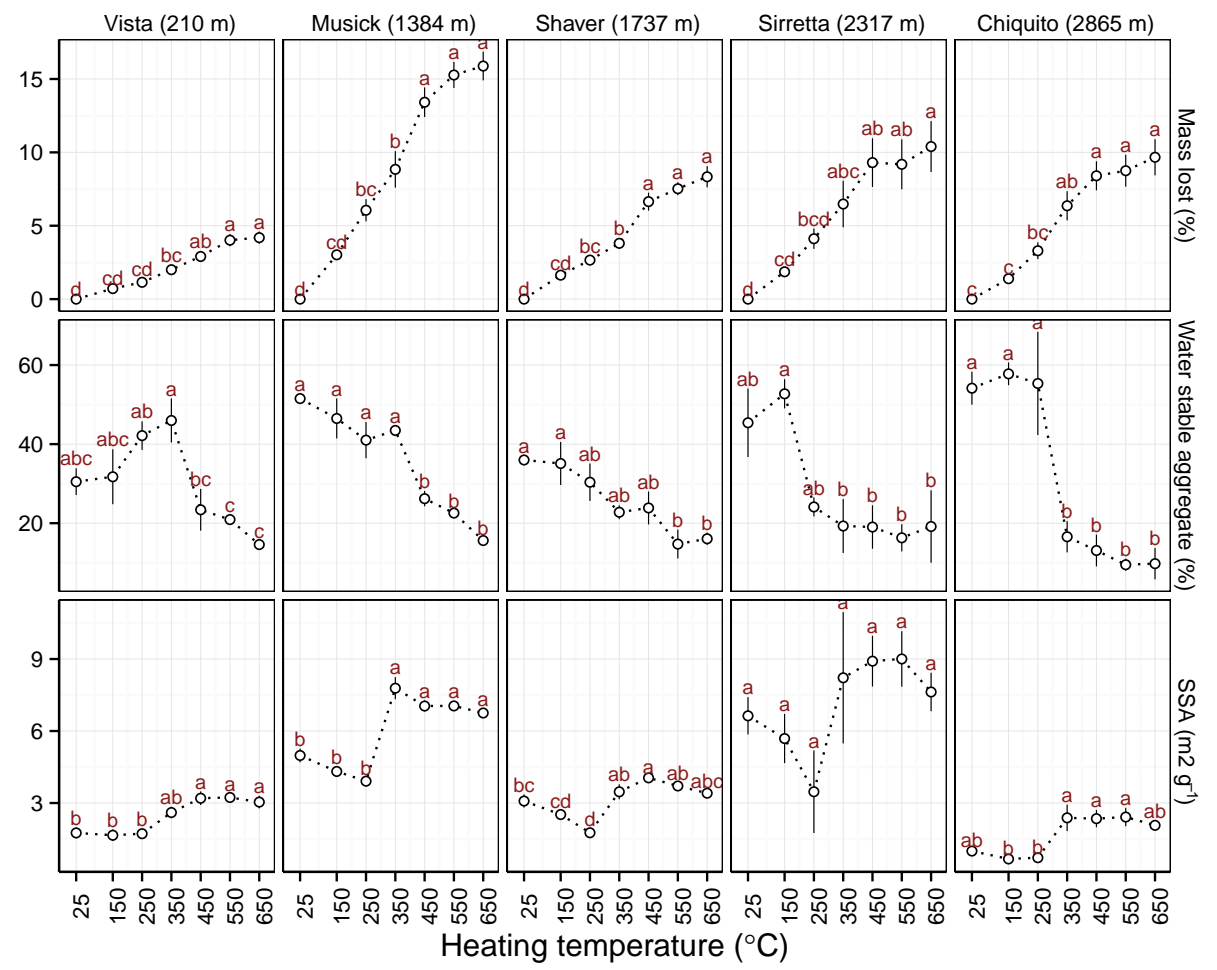

Figure 4. Percent mass lost, water-stable aggregate percent and specific surface area changes with increase in heating temperatures. Error bars represent standard error where $n=3$. Different letters represent significantly different means $(p<0.05)$ at temperature after Tukey's HSD testing.

aggregate strength, compared to unburned samples, was observed only at higher temperatures above $350^{\circ} \mathrm{C}$ for Sirretta (2317 $\mathrm{m}$ a.s.l.) and Chiquito (2865 $\mathrm{m}$ a.s.l.) soils, and above $450^{\circ} \mathrm{C}$ for Musick (1384 ma.s.l.), Vista (210 ma.s.l.) and Shaver (1737 m a.s.l.) soils (Fig. 4).

Although not statistically significant, all soils showed a decrease in macro-aggregate fraction accompanied by an increase in micro-aggregate and silt-clay sized fractions (Fig. 5). For the two lower elevation soils (Vista and Musick) the decrease in macro-aggregate fraction was over $10 \%$ and less than $5 \%$ for all the other soils. Only Musick (1384 $\mathrm{m}$ a.s.l.) soils showed a statistically significant decrease in macro-aggregate fraction between 150 and $350^{\circ} \mathrm{C}$ temperatures.

\subsection{Specific surface area}

For all soils, we observed a stepwise increase in specific surface area (SSA) for samples that were heated to between 250 and $450^{\circ} \mathrm{C}$ (Fig. 4). Changes in SSA between soils heated below $250^{\circ} \mathrm{C}$ and those heated above $450^{\circ} \mathrm{C}$ were statistically significant at $p<0.05$ for all soils, except the high elevation soils Sirretta (2317 $\mathrm{m}$ a.s.l.) and Chiquito (2865 m a.s.l.). Sirretta soils showed a lot of variability and did not show any significant change in SSA throughout the temperature range while the Chiquito soil showed sta-

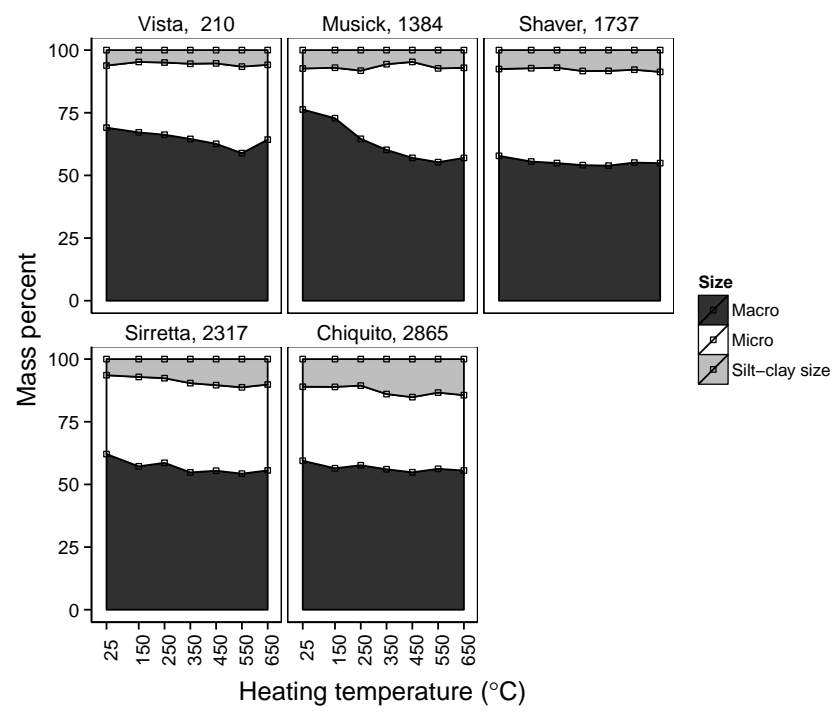

Figure 5. Weight fraction of aggregate sizes: macro $(2-0.25 \mathrm{~mm})$, micro $(0.25-0.053 \mathrm{~mm})$ and silt-clay $(<0.053 \mathrm{~mm})$ sizes.

tistically significant increase between low temperature 150 $250^{\circ} \mathrm{C}$ and higher temperature $350-550^{\circ} \mathrm{C}$ range. The pattern of change in SSA with temperature was similar for all soils. The lowest SSA was recorded for all soils when soils 
were heated at $250{ }^{\circ} \mathrm{C}$, and highest SSA was observed at $350{ }^{\circ} \mathrm{C}$ (for Musick and Chiquito soils) or $450^{\circ} \mathrm{C}$ (Vista and Shaver soils).

\subsection{Soil mineralogy}

The bulk soil XRD results of changes in soil mineralogy in response to heating are presented for basic mineral groups as feldspar (microcline and orthoclase); plagioclase (albite and oligoclase); amphibole; mica/illite (biotite); kaolinite; gibbsite; and expandable phyllosilicate (montmorillonite and vermiculite). We identified vermiculite with low confidence, since we did not correct with oriented clay treatments, hence it is not certain if the identified peaks are indeed representative of vermiculite, chlorite, or both. The XRD diagrams showed some significant transformations in soil mineralogy with heating, with shifted peaks at higher temperatures suggesting transformation of clay minerals. Layer silicates appeared to collapse structurally, possibly due to dehydration and the removal of $\mathrm{OH}$ (Fig. 6). Summary mineral composition changes identified from XRD analysis using Rietveld method are presented in Fig. 7. From the minerals identified, the concentration of kaolinite was the most affected by heating. In all soils, concentration of kaolinite showed a decrease when heated to $550^{\circ} \mathrm{C}$ and above. Gibbsite was also not detected in soils heated to $>450^{\circ} \mathrm{C}$. Furthermore, mica/illite, plagioclases and amphibole mineral groups changed consistently with increasing temperature. The largest change in soil mineralogy with heating was observed for the mid-elevation Music (1384 m a.s.1.) and Shaver (1737 $\mathrm{m}$ a.s.1.) soils that are also among the most developed soils with highest proportions of the $1: 1$ clay minerals (kaolinite).

\subsection{Soil pH}

With increase in temperature, all soils showed a similar pattern of increase in $\mathrm{pH}$ (Fig. 8). For all soils the largest increase in $\mathrm{pH}\left(2.5-5\right.$ units) occurred between 250 and $450{ }^{\circ} \mathrm{C}$. All the soils started out with slightly to moderately acidic $\mathrm{pH}$ with the exception of Chiquito (2865) soils. Yet, all soils became alkaline at temperatures above $450{ }^{\circ} \mathrm{C}$. The largest increase in $\mathrm{pH}$ was observed for the Musick (1384 m a.s.1.) soils which reached a pH of 10 at temperatures above $550^{\circ} \mathrm{C}$.

\subsection{Cation exchange capacity}

The CEC of studied soils ranged from an average of $6 \mathrm{cmol}_{\mathrm{c}} \mathrm{kg}^{-1}$ for Chiquito $(2865 \mathrm{~m}$ a.s.1.) soils to $25 \mathrm{cmol}_{\mathrm{c}} \mathrm{kg}^{-1}$ for Musick (1384 ma.s.l.) soils. With an increase of heating temperature all soils showed a continued decrease of CEC. With the exception of Musick (1384 m a.s.1.) soils, CEC eventually dropped to below our detection limit $\left(2 \mathrm{cmol}_{\mathrm{C}} \mathrm{kg}^{-1}\right)$ at a temperature above $550{ }^{\circ} \mathrm{C}$ (Fig. 8). For the poorly weathered Chiquito (2865 ma.s.1.) soils, CEC was below $2 \mathrm{cmol}_{\mathrm{c}} \mathrm{kg}^{-1}$ at temperatures $250{ }^{\circ} \mathrm{C}$

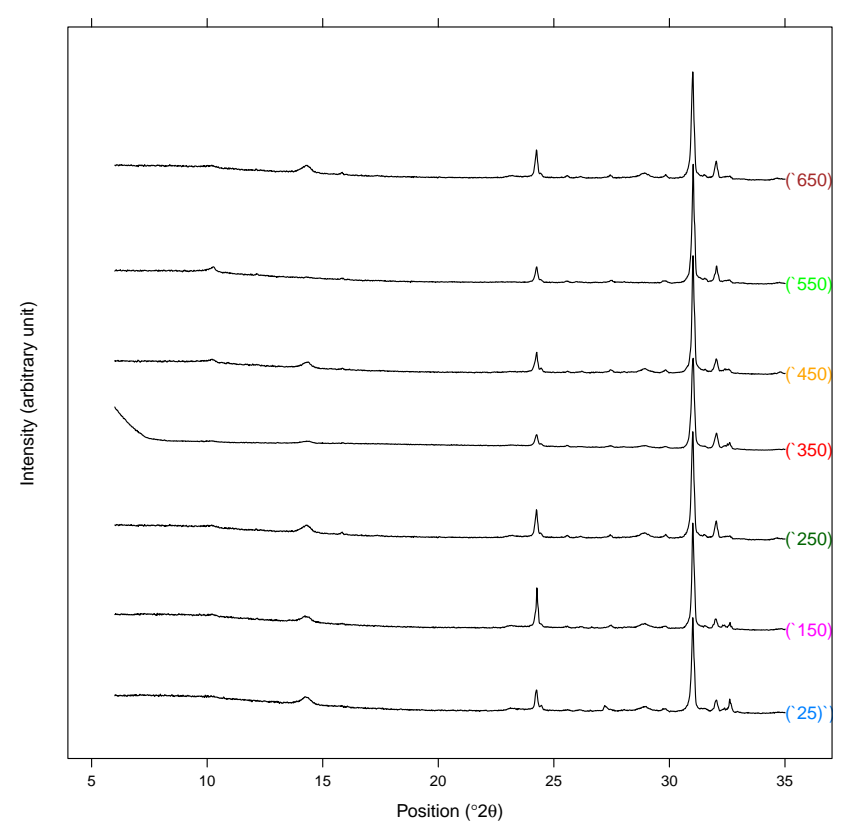

Figure 6. XRD diagram for Music series soils.

and above. For the rest of the soils, statistically significant changes in CEC $(p<0.05)$ occurred at $450{ }^{\circ} \mathrm{C}$ with the exception of Musick (1384 m a.s.1.) soils which showed a statistically significant drop at $250{ }^{\circ} \mathrm{C}$ and again $350^{\circ} \mathrm{C}$. At $350^{\circ} \mathrm{C}$, all the soils except Musick (1384 ma.s.1.) showed a slightly higher $\mathrm{CEC}$ than at $250^{\circ} \mathrm{C}$ thus interrupting a continuous pattern of the CEC decrease with an increase in temperature.

\subsection{Carbon and nitrogen concentration}

The initial concentration of $\mathrm{C}$ ranged from $1.5 \%$ (Vista soil, $210 \mathrm{~m}$ a.s.1.) to $7.7 \%$ (Musick soils, $1384 \mathrm{~m}$ a.s.1.). Soil $\mathrm{C}$ concentration decreased with an increase in temperature (Fig. 9) with the largest decrease occurring between temperatures of 250 and $450{ }^{\circ} \mathrm{C}$. At $450^{\circ} \mathrm{C}$, all soils had lost more than $95 \%$ of their initial C. At temperatures above $450^{\circ} \mathrm{C}$, $\mathrm{C}$ concentration changes were small and we did not find statistically significant changes at $p<0.05$. The $\mathrm{C}: \mathrm{N}$ ratio ranged from 10 (Vista soils, $210 \mathrm{~m}$ a.s.1.) to 29 (Musick soils, $1384 \mathrm{~m}$ a.s.1.). The $\mathrm{C}: \mathrm{N}$ ratio decreased with an increase in heating temperature in a similar pattern to the $\mathrm{C}$ concentration (Fig. 9).

The loss of $\mathrm{C}$ and $\mathrm{N}$ from soils due to heating showed a similar response among all five soils. After $250^{\circ} \mathrm{C}$, all the soils lost more than $25 \%$ of their initial C (except Shaver soils that lost only about $10 \%$ ). At $350{ }^{\circ} \mathrm{C}$ all soils lost 50 to $70 \%$ of $\mathrm{C}$. Heating at $450{ }^{\circ} \mathrm{C}$ led to the loss of more than $95 \%$ of their initial $\mathrm{C}$ for all soils in this study. Loss of $\mathrm{N}$ was lower than that of $\mathrm{C}$. At temperatures greater than $550^{\circ} \mathrm{C}$ there was 5 to $15 \%$ of soil $\mathrm{N}$ still remaining. Consequently, 

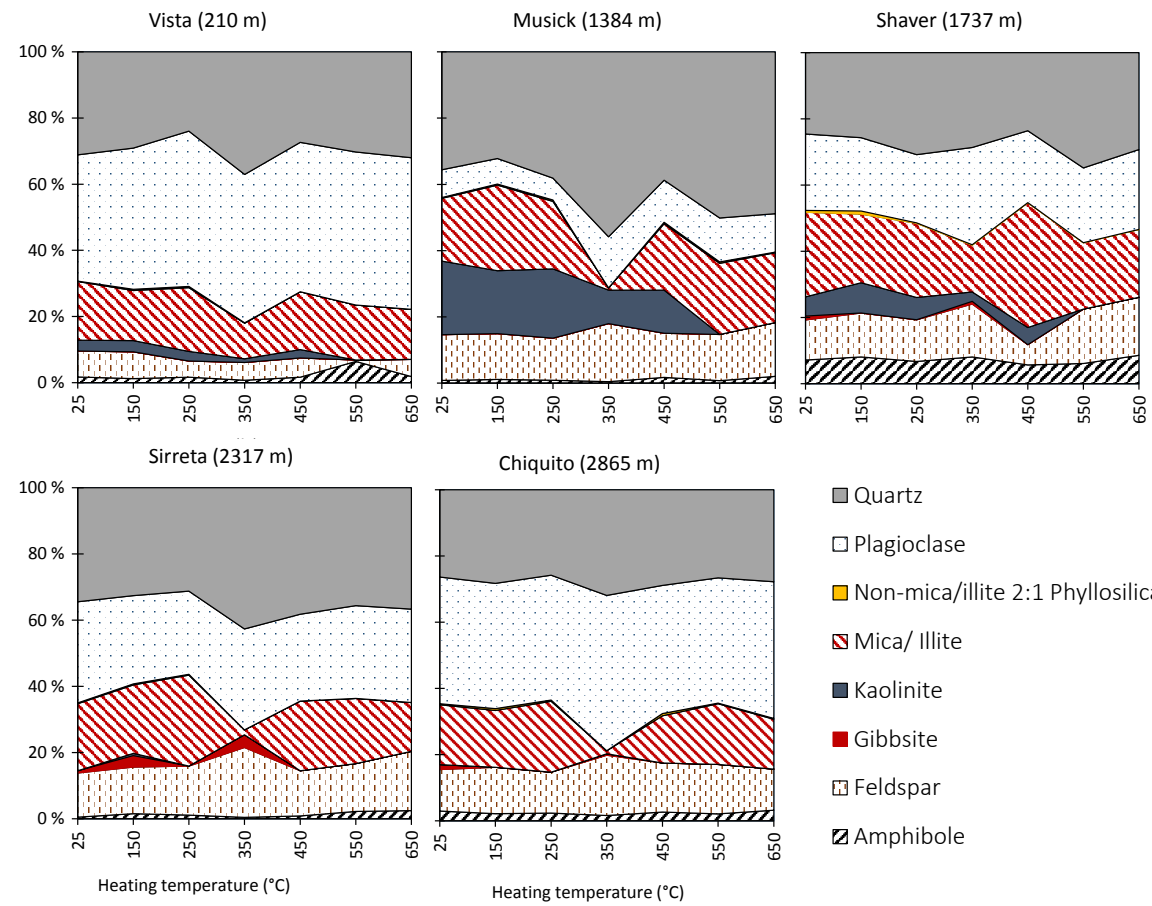

$\square$ Quartz

$\square$ Plagioclase

$\square$ Non-mica/illite 2:1 Phyllosilicates

\$ Mica/ Illite

口Kaolinite

- Gibbsite

G] Feldspar

$\square$ Amphibole

Figure 7. Relative amounts of minerals identified from powder XRD.

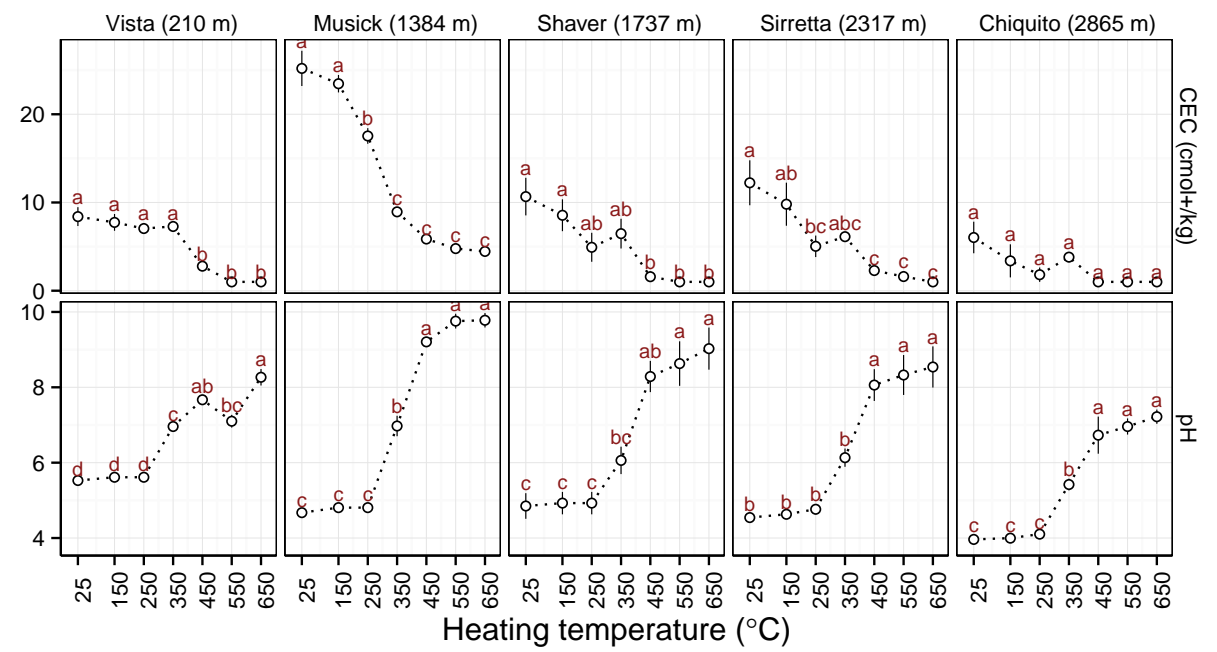

Figure 8. $\mathrm{pH}$ (geometric means) and cation exchange capacity (adjusted for mass loss) changes with increase in heating temperature. CEC values below the $2 \mathrm{cmol}_{\mathrm{c}} \mathrm{kg}^{-1}$ are assigned a value of 1 for plotting. Error bars represent standard error where $n=3$. Different letters represent significantly different means $(p<0.05)$ at each temperature after Tukey's HSD testing.

we observed a decrease of $\mathrm{C}: \mathrm{N}$ ratio with increase in heating temperature. All soils continued to lose about $15 \%$ soil N for every $100^{\circ} \mathrm{C}$ increase and maintained more than $60 \%$ of their $\mathrm{N}$ at heating temperatures up to $350{ }^{\circ} \mathrm{C}$. After heating at $450^{\circ} \mathrm{C}$, all soils lost more than $60 \%$ of the initial soil $\mathrm{N}$ and $85 \%$ by $550^{\circ} \mathrm{C}$.

\section{Discussion}

The topsoil layer is most affected by extreme temperature during vegetation fires. Our results show significant changes in soil properties as a result of temperature exposure. Our findings demonstrate that alterations and loss of SOM in topsoil because of heating, rather than alterations to soil minerals, was the most important driver for the observed changes in soil physico-chemical properties. Our XRD anal- 


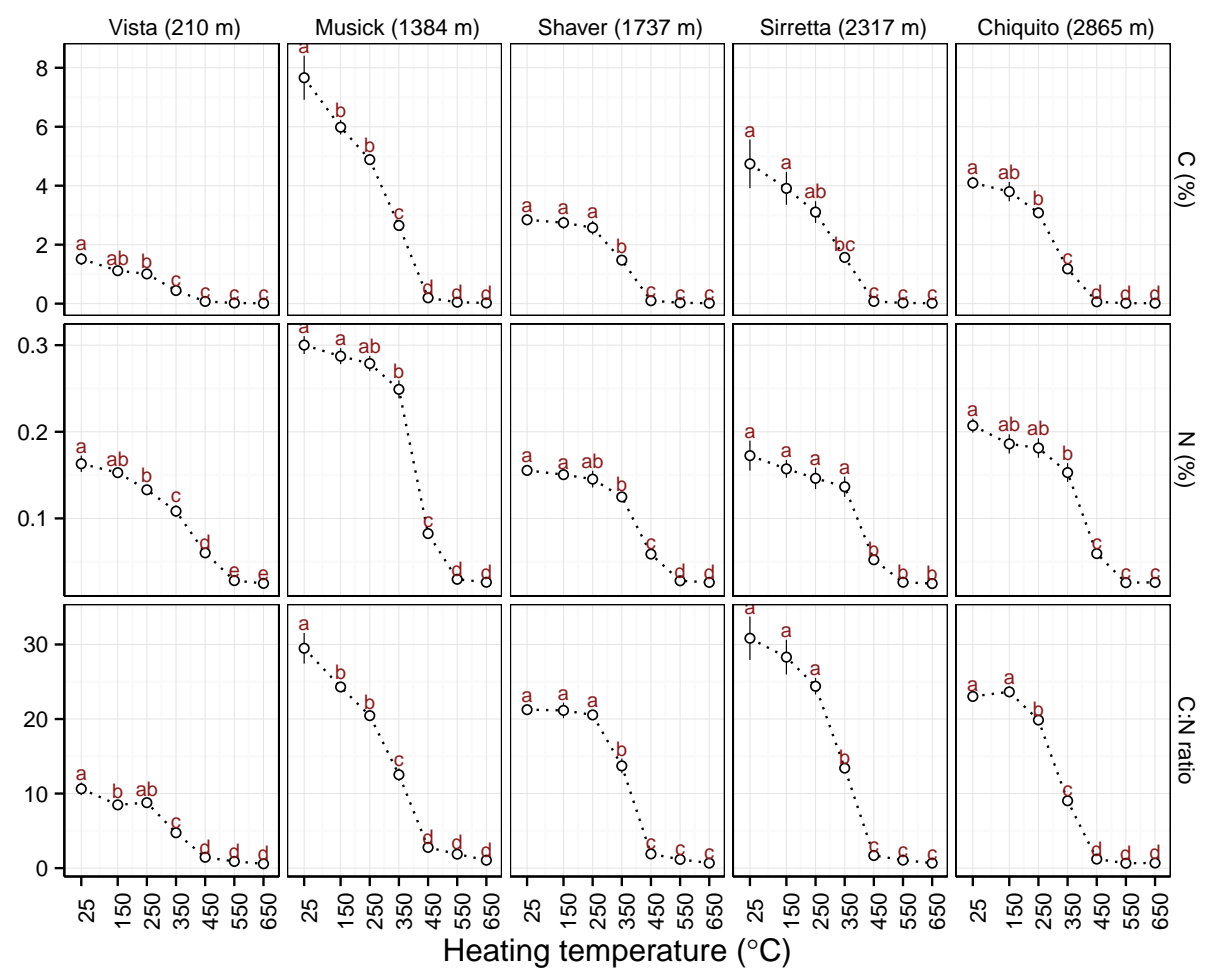

Figure 9. Carbon concentration, Nitrogen concentration and $\mathrm{C}: \mathrm{N}$ atomic ratio changes with increase in heating temperature. Error bars represent standard error where $n=3$. Different letters represent significantly different means $(p<0.05)$ at each temperature after Tukey's HSD testing.

ysis shows notable changes in soil mineralogy only after the soils were heated to about 450 to $550^{\circ} \mathrm{C}$ (Fig. 7). In upland ecosystems, such as the Sierra Nevada Mountains, the soils typically have low clay content and low concentration of secondary minerals (Neary et al., 1999; Ubeda and Outeiro, 2009). In addition, these upland temperate ecosystems also tend to have relatively high concentration of SOM, including a fairly well-developed O-horizon. Consequently, strong relationships are observed between SOM concentrations and the soils' physical and chemical properties. Simple linear regression analyses between $\mathrm{C}$ concentration changes and other soil physical and chemical changes for our study soils shows that more than $80 \%$ of the variability in mass loss, aggregate strength, SSA, $\mathrm{pH}, \mathrm{CEC}$ and $\mathrm{N}$ concentrations are associated with changes in $\mathrm{C}$ concentration at the different heating temperatures. Table 3 summarizes the correlation coefficients of soil property changes with changes in C concentration.

The changes in soil color observed were consistent with the charring of SOM which leads to darkening of the brownish color of the soils. At temperatures over $450{ }^{\circ} \mathrm{C}$, the near complete removal of SOM by combustion and the addition of ash products likely explains the observed lighter color of soils. The increase in Munsell chromas and reddening of soils at these high temperatures has been noted in previous works (e.g. Giovannini et al., 1988; Ketterings and Bigham, 2000;
Ulery and Graham, 1993) and is likely a result and the transformation of iron oxides that occurs during heating.

The extent of mass loss in topsoil layers due to vegetation fires is strongly correlated to SOM combustion (Rein et al., 2008). In all of our soils, statistically significant mass loss $(p<0.05)$ occurred within the temperature ranges of SOM combustion, between 250 to $450^{\circ} \mathrm{C}$. Proportion of soil mass loss with temperature was proportional to initial $\mathrm{C}$ concentration of the soils. For example, Musick (1384 m a.s.l.) soils which had the highest initial $\mathrm{C}$ concentration $(7.7 \%)$ had the steepest soil mass loss and lost $15 \%$ of mass at $550^{\circ} \mathrm{C}$, while Vista (210 m a.s.1.) which had less than $2 \% \mathrm{C}$ concentration showed the smallest mass loss losing less than $5 \%$ mass even at the highest temperature. Mass loss at temperatures below $250^{\circ} \mathrm{C}$ is likely driven by dehydration processes rather than by loss of SOM. On the other hand, mass loss at temperatures above which $\mathrm{SOM}$ combusts, $>450{ }^{\circ} \mathrm{C}$, is likely driven by charring, ashing and volatilization processes.

Most studies report significant soil aggregate stability reduction with fire heating (e.g. Arcenegui et al., 2008; Zavala et al., 2010), however, contrasting findings are also reported in other studies. Mataix-Solera et al. (2011) explains that increase in aggregate strength with heating is possible in clay-rich soils where the main cementing agents are inorganic minerals such as calcium carbonates and metallic oxides which would fuse under fire heating increasing aggre- 
Table 3. Linear correlation coefficients of changes in soil properties with changes in $\mathrm{C}$ concentration.

\begin{tabular}{lcccccc}
\hline Soil & \multicolumn{5}{c}{ Correlation coefficient $\left(r^{2}\right)$ values } \\
\cline { 2 - 7 } & $\begin{array}{c}\text { Mass } \\
\text { loss }\end{array}$ & SSA & $\begin{array}{c}\text { Aggregate } \\
\text { stability }\end{array}$ & $\begin{array}{c}\mathrm{pH} \\
\left(\mathrm{CaCl}_{2}\right)\end{array}$ & $\mathrm{CEC}$ & $\begin{array}{c}\mathrm{N} \\
\text { concentration }\end{array}$ \\
\hline Vista & 0.74 & 0.73 & 0.21 & 0.77 & 0.78 & 0.89 \\
Musick & 0.89 & 0.58 & 0.77 & 0.89 & 0.96 & 0.83 \\
Shaver & 0.82 & 0.58 & 0.68 & 0.74 & 0.78 & 0.93 \\
Sirretta & 0.60 & 0.34 & 0.47 & 0.67 & 0.87 & 0.86 \\
Chiquito & 0.82 & 0.62 & 0.78 & 0.88 & 0.44 & 0.87 \\
\hline
\end{tabular}

gate stability. Another possibility is, soils which initially had weak hydrophobicity may show increased aggregate stability due to increase in hydrophobicity, in such cases however aggregate strength would decline at higher severity fires as hydrophobicity is destroyed.

Aggregate stability in all our soils generally decreased with increase in heating temperature. Although we did not find a statistically significant difference, it is worth noting that the lowest elevation soil (Vista, $210 \mathrm{~m}$ a.s.1.) showed a trend of aggregate stability increase up to $350^{\circ} \mathrm{C}$ while the high elevation soils, Sirretta (2317 $\mathrm{m}$ a.s.1.) and Chiquito (2865 $\mathrm{m}$ a.s.1.), showed a slight increase in aggregate stability at $150^{\circ} \mathrm{C}$. An increase in hydrophobicity at these temperatures is the most likely cause, substantial hydrophobicity was apparent with Chiquito soils $\left(2865 \mathrm{~m}\right.$ a.s.l.) heated at $250^{\circ} \mathrm{C}$ where resistance to slaking was remarkably evident during the aggregate stability test.

Soil specific surface area (SSA) is an important soil property that affects soil adsorption, ion exchange capacity, reactivity, aggregation and porosity (Feller et al., 1992). SSA of soil is largely dictated by clay-size particles and SOM (Carter et al., 1986). The increase in SSA with heating that we observed in this work is most likely the result of physical disintegration and charring of SOM, especially at temperatures below $500^{\circ} \mathrm{C}$. Changes in soil mineralogy are not likely to be responsible for the changes in SSA we observed. XRD analysis showed notable mineralogical changes only at temperatures above $450^{\circ} \mathrm{C}$ where the kaolinite peak disappeared at $550{ }^{\circ} \mathrm{C}$ and the phyllosilicate peaks were diminished or disappeared at $450-550^{\circ} \mathrm{C}$ (e.g. Fig. 6). Because of combustion, pyrolysis and thermal dehydration, larger organic matter particles are likely to have fragmented and reduced in size with an increase in heating temperature leading to increase in bulk soil SSA. Furthermore, thermal alteration and the removal of organic matter from mineral surfaces may have increased surface area by reducing the size of particles. At higher temperatures $\left(>450^{\circ} \mathrm{C}\right)$, XRD spectra showed some collapse of mineral complexes through dehydration and dehydroxylation of clay minerals that may reduce mineral particle size and increase surface area. These changes in mineralogy might have a significant effect on SOM. A study by Rosa et al. (2013) found that soils released more organic compounds during pyrolysis when the soils were treated with $\mathrm{HF}$ acid, suggesting that mineral complexes play a role in protecting organic compounds from pyrolysis. The collapse of mineral complexes we observed and the decrease in aggregate strength is likely to have enhanced thermal oxidation of SOM. However mineralogical changes would play a more important role affecting soil properties at these high temperatures since SOM has been almost completely removed.

Soil $\mathrm{pH}$ generally increases with fire heating (Badía and Martí, 2003b; Chandler et al., 1983; Ubeda and Outeiro, 2009). In a soil heating experiment similar to our study, Fernández et al. (1997) observed a pH increase of 1.7 at $350{ }^{\circ} \mathrm{C}$ and 2.35 at $490^{\circ} \mathrm{C}$. Such increase in soil $\mathrm{pH}$ has been attributed to the denaturation of organic acids, release of base cations from combustion (K- and Na-hydroxides, $\mathrm{Mg}$ - and Ca-carbonates), deposition of ashes, and loss of hydroxyl groups from clays (Badía and Martí, 2003b; Certini, 2005; Ulery et al., 1993). In our soils, the higher elevation soils (Shaver, Sirretta and Chiquito) showed a statistically insignificant decrease of 0.3 to $0.5 \mathrm{pH}$ units (measured in water) at $250^{\circ} \mathrm{C}$. The change in $\mathrm{pH}$ in our highelevation soils was consistent with previous results of Badía and Martí (2003b) and Terefe et al. (2008) that found a similar initial decrease. Terefe et al. (2008) hypothesized that this may be due to the combined effect of desiccation and heating effect which favor proton-reducing oxidation reactions. And the fact that this initial increase occurs below the temperature for the start of combustion of organic acids means contribution of SOM to this $\mathrm{pH}$ increase (organic acid denaturation and ash liming effect) was absent at this temperature. In a similar heating experiment Badía and Martí (2003b) found an increase in electric conductivity and soluble $\mathrm{Ca}$ along with decrease in $\mathrm{pH}$ at $250^{\circ} \mathrm{C}$. Such increase in soluble cations might explain our findings where we observed a decrease in $\mathrm{pH}$ when measured in water but not in $\mathrm{CaCl}_{2}$ suggesting that the decrease in $\mathrm{pH}$ might have to do with increase of soluble salts with heating up to $250^{\circ} \mathrm{C}$.

The capacity of soil to exchange positively charged ions between soil and soil solution (CEC) decreased with increasing temperature. CEC of soils is a result of surface charges associated with secondary clay minerals and SOM (Sparks, 2003), and in our study soils, Dahlgren et al. (1997) had previously reported a strong relationship of CEC with soil organic carbon and clay concentrations. Different authors have attributed loss of CEC during heating mainly with loss of SOM (Fernández et al., 1997; Ubeda and Outeiro, 2009) partly because CEC loss starts to be observed at temperatures above $200^{\circ} \mathrm{C}$ with little or no decrease at lower temperatures where SOM is not affected (Nishita and Haug, 1972; Soto and Diazfierros, 1993). The slight increase of CEC we observed at $350^{\circ} \mathrm{C}$ may be due to the steep increase of specific surface area at that temperature (Fig. 4). The additional surface for cation adsorption might have to an extent compensated for the loss of SOM at that temperature. Furthermore, the contribution of surface oxidation of char products 
has been shown to increase CEC per unit C (Liang et al., 2006) because of the almost complete loss of $C$ at temperatures above $450^{\circ} \mathrm{C}$ and very little loss at temperatures below $250^{\circ} \mathrm{C}$. The soils most likely had highest concentration of charred SOM at $350^{\circ} \mathrm{C}$ temperature.

\subsection{Importance of the $250-450^{\circ} \mathrm{C}$ range}

Taking maximum surface temperature as a metric of fire intensity, low-intensity fires reach surface temperatures of up to $250^{\circ} \mathrm{C}$, medium-intensity fires reach surface temperatures of $400^{\circ} \mathrm{C}$, and high-intensity fires reach surface temperatures above $675^{\circ} \mathrm{C}$ (Janzen and Tobin-Janzen, 2008). In this study, the most significant changes of soil chemical properties occurred between 250 and $450{ }^{\circ} \mathrm{C}$. Figure 10 illustrates the changes between unburned and $650^{\circ} \mathrm{C}$ burned soils and the amount of change that occurred within 250 to $450{ }^{\circ} \mathrm{C}$ heating temperature for a range of the variables discussed above. In all cases, the change in the $250-450{ }^{\circ} \mathrm{C}$ range accounts for most of the total change observed during our heating treatments. Among the variables we investigated in this study, we observed changes along two general lines: (1) mass loss, SSA and $\mathrm{pH}$ which showed a progressive increase with heating temperature, and (2) \% $\mathrm{C}, \% \mathrm{~N}, \mathrm{C}: \mathrm{N}$ ratio, $\mathrm{CEC}$, and wet aggregate stability that showed a progressive decrease with increase in temperature (Fig. 10), with the most significant changes in all cases being recorded in all soils between 250 and $450{ }^{\circ} \mathrm{C}$.

Temperatures below $250^{\circ} \mathrm{C}$ are very critical for many processes, water is lost at $95^{\circ} \mathrm{C}$ and this has a significant effect on soil heat conduction and soil biota (Janzen and TobinJanzen, 2008). However, we found that temperatures below $200^{\circ} \mathrm{C}$ have very little effect on quality or quantity of SOM. This implies that lower intensity fires, such as typical prescribed fires, where soil surface temperatures do not exceed $250{ }^{\circ} \mathrm{C}$ temperature contribute little to soil C loss. Similarly, temperatures above $500^{\circ} \mathrm{C}$ do little to SOM, which already has been lost or transformed into a pyrogenic product. The effect on soil inorganic particles starts at high temperature but the significance of change on minerals is not as large (Fig. 1). Hence, we found that the most important soil changes occur at the $250-450{ }^{\circ} \mathrm{C}$ range.

Important modifications of fire conditions that still allow for a comparison of responses of different types of soils have to be adopted to conduct the type of heating experiments that we undertook in this work. A heating rate of $3{ }^{\circ} \mathrm{C} \mathrm{min}^{-1}$ is common in laboratory soil heating studies, often because of technical considerations and because such a slow rate prevents sudden combustion which otherwise would happen as soil's ignition temperature is reached at about $220^{\circ} \mathrm{C}$ (Fernández et al., 1997, 2001; Varela et al., 2010). However, it is important to recognize that during vegetation fires the rate of temperature increase experienced by the topmost layer of soil that is exposed to fire can be significantly higher. The rate of heating alone might have additional significant effects on soil properties beyond what we observe here. For example, Albalasmeh et al. (2013) found that slow rate of heating underestimates soil aggregate destruction of moist soils due to a slower buildup of pore-pressure.

\subsection{Climate change implications}

Investigation of the response of climosequence soils to different heating temperature in this study enables us to infer how changes in climate (and associated changes in soil properties) are likely to alter the effect of fires on topsoil physical and chemical properties. The overall pattern of soil property changes with increase in heating temperature were similar for all soils, however, the magnitudes of change were variable. Hence, these findings lead us to conclude that climate change is likely to alter the response of topsoil properties to different fire regimes. Along our study climosequence, we observed critical differences in the response of topsoils based mostly on concentration OM in soil and soil development stages of each soil - both variables that are expected to respond to changes in climate (Berhe et al., 2012). Consequently, changes in soil $\mathrm{C}$ storage associated with climate change are expected to lead to different amounts of $\mathrm{C}$ loss due to fires. This is evidenced by the observed highest total mass of $\mathrm{C}$ loss from the mid-elevation Musick soil that had the highest carbon stock, compared to soils on either side of that elevation range. Anticipated changes in climate in the Sierra Nevada mountain ranges are expected to include upward movement of the rain-snow transition line exposing areas that now receive most of their precipitation as snow to rainfall and associated runoff (Arnold et al., 2014, 2015; Stacy et al., 2015). Moving of the rain-snow transition zone higher and promotion of more intense weathering at higher elevation zones then is likely to render more $\mathrm{C}$ to loss during fires. As we found in this study, more than $80 \%$ of the variability in mass loss, aggregate strength, SSA, pH, CEC and $\mathrm{N}$ concentrations is associated with changes in $\mathrm{C}$ concentration at the different heating temperatures (Table 3). Improving our understanding of how topsoil properties are likely to respond to changes in climate becomes even more critical when we recognize that $C$ concentration in soil is likely to respond quickly to changes in climate, compared to other soil physical and chemical properties (Berhe et al., 2012). Furthermore, the long-term fate of soil carbon in fire-affected ecosystems is also likely to be accompanied by changes in microbial community composition and OM decomposition kinetics (Holden et al., 2015; Tas et al., 2014) which are likely to have further implications for nutrient availability post-fire (Johnson et al., 1997, 2007).

The different responses of soil aggregation in our climosequence to the treatment temperatures also suggest potential loss and transformation of the physically protected $\mathrm{C}$ pool in topsoil. Degradation of aggregates during fire (Albalasmeh et al., 2013) is likely to render aggregate-protected C to potential loses through oxidative decomposition, leach- 

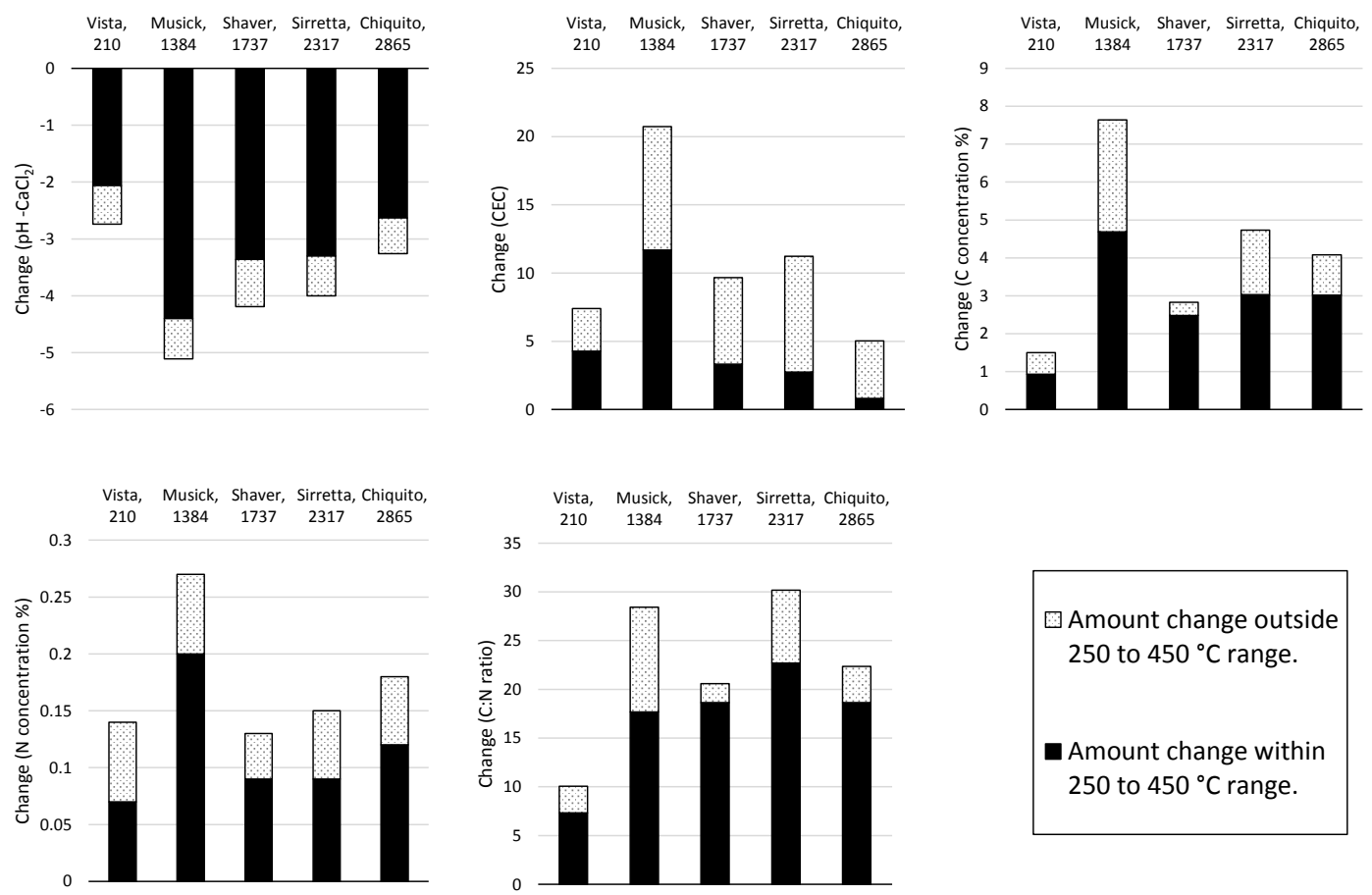

Figure 10. Total amount of change from unburned to $650^{\circ} \mathrm{C}$ combusted soils showing amount of change within the 250 to $450^{\circ} \mathrm{C}$ range.

ing and erosion. Moreover, in systems such as the Sierra Nevada where steep slopes and organic matter-rich topsoils dominate, movement of the rain-snow transition zone upward is likely to increase proportion of precipitation that occurs as rain. The kinetic energy of raindrops and observed increase in hydrophobicity of soils post-fires (Johnson et al., 2004 , 2007) can lead to higher rates of erosional redistribution of especially the free light fraction or particulate $\mathrm{C}$ that is not associated with soil minerals (Stacy et al., 2015). Moreover, the important differences in changes in $\mathrm{pH}$, mineralogy, CEC in response to heating at different temperatures that we observed for soils along the climosequence suggest that changes in temperature are likely to lead to different effects on soil chemical properties in soils after fires.

Finally, with changes in climate it is anticipated that fires will increase in severity (Westerling et al., 2006). Our findings of important changes in soil physical and chemical properties occurring between $250-450^{\circ} \mathrm{C}$ are important for recognizing that critical transformations of topsoil physical and chemical properties are likely to occur when, as a result of climate change, systems that are adapted to low severity fires experience medium to high severity fires.

\section{Conclusion}

The findings of this study showed that changes in soil properties during heating are closely related to changes in $\mathrm{C}$ concentrations in soil. The temperatures most critical to $\mathrm{C}$ loss and alteration were found to be $250^{\circ} \mathrm{C}$, where charring of organic matter starts and $450{ }^{\circ} \mathrm{C}$ where most of the SOM is combusted. Most soil properties exhibited a steep change in this temperature range. Soil aggregate stability, CEC, and C and $\mathrm{N}$ concentrations significantly decreased with increase in heating temperature while soil $\mathrm{pH}$ and SSA significantly increased. The most important effect of heating on soil mineralogy as observed by XRD analysis was the disappearance of kaolinite, which was undetectable at temperatures above $500^{\circ} \mathrm{C}$.

This study presented the effects of heat input on topsoil properties. The study is necessary to understand thermally induced changes on soil properties in isolation from other variables that accompany vegetation fires such as the addition of pyrolysis products from plants and ash, and the fire-induced soil moisture dynamics. Findings from this study will contribute towards estimating the amount and rate of change in carbon and nitrogen loss, and other essential soil properties that can be expected from topsoil exposure to different intensity fires under anticipated climate change scenarios.

\section{The Supplement related to this article is available online at doi:10.5194/soil-2-351-2016-supplement.}

Acknowledgements. The authors would like to thank Randy A. Dahlgren for providing us with geo-references for the study sites, background data, and for his comments on an earlier version of this manuscript. We thank Marilyn Fogel and Christina Bradley for their help and expertise in elemental analysis 
of C and N; and Samuel Traina for his comments on an earlier version of this manuscript. The research was funded by a UC Merced Graduate Research Council grant and NSF grant (EAR-1352627) to $\mathrm{AAB}$.

Edited by: A. Jordán

Reviewed by: X. Huang, G. M. Davies, and one anonymous referee

\section{References}

Albalasmeh, A. A., Berli, M., Shafer, D. S., and Ghezzehei, T. A.: Degradation of moist soil aggregates by rapid temperature rise under low intensity fire, Plant Soil, 362, 335-344, doi:10.1007/s11104-012-1408-z, 2013.

Arcenegui, V., Mataix-Solera, J., Guerrero, C., Zomoza, R., Matalx-Beneyto, J., and Garcia-Orenes, F.: Immediate effects of wildfires on water repellency and aggregate stability in Mediterranean calcareous soils, Catena, 74, 219-226, doi:10.1016/j.catena.2007.12.008, 2008.

Arnold, C., Ghezzehei, T. A., and Berhe, A. A.: Early spring, severe frost events, and drought induce rapid carbon loss in high elevation meadows, PloS One, 9, e106058, doi:10.1371/journal.pone.0106058, 2014.

Arnold, C., Ghezzehei, T. A., and Berhe, A. A.: Decomposition of distinct organic matter pools is regulated by moisture status in structured wetland soils, Soil Biol. Biochem., 81, 28-37, doi:10.1016/j.soilbio.2014.10.029, 2015.

Badía, D. and Martí, C.: Effect of simulated fire on organic matter and selected microbiological properties of two contrasting soils, Arid Land Res. Manage., 17, 55-69, doi:10.1080/15324980301594, 2003a.

Badía, D. and Martí, C.: Plant ash and heat intensity effects on chemical and physical properties of two contrasting soils, Arid Land Res. Manage., 17, 23-41, doi:10.1080/15324980301595, $2003 \mathrm{~b}$

Berhe, A. A., Suttle, K. B., Burton, S. D., and Banfield, J. F.: Contingency in the Direction and Mechanics of Soil Organic Matter Responses to Increased Rainfall, Plant Soil, 358, 371-383, doi:10.1007/s11104-012-1156-0, 2012.

Bowman, D. M. J. S., Balch, J. K., Artaxo, P., Bond, W. J., Carlson, J. M., Cochrane, M. A., D'Antonio, C. M., DeFries, R. S., Doyle, J. C., Harrison, S. P., Johnston, F. H., Keeley, J. E., Krawchuk, M. A., Kull, C. A., Marston, J. B., Moritz, M. A., Prentice, I. C., Roos, C. I., Scott, A. C., Swetnam, T. W., van der Werf, G. R., and Pyne, S. J.: Fire in the Earth System, Science, 324, 481-484, doi:10.1126/science.1163886, 2009.

Caldararo, N.: Human ecological intervention and the role of forest fires in human ecology, Sci. Total Environ., 292, 141-165, doi:10.1016/S0048-9697(01)01067-1, 2002.

California Department of Water Resources: Water Conditions in California, Bull. 120, Sacramento, 1952-1962.

Caprio, A. C. and Swetnam, T. W.: Historic fire regimes along an elevational gradient on the west slope of the Sierra Nevada, California, General Technical Report INT-GTR-320, US Department of Agriculture, Forest Service, Intermountain Research Station, Ogden, UT, 173-179, 1995.

Carroll, E. M., Miller, W. W., Johnson, D. W., Saito, L., Qualls, R. G., and Walker, R. F.: Spatial analysis of a large magnitude erosion event following a Sierran wildfire, J. Environ. Qual., 36, 1105-1111, doi:10.2134/jeq2006.0466, 2007.

Carter, D. L., Mortland, M. M., and Kemper, W. D.: Specific surface area, in: Methods of Soil Analysis, Part 1, Agronomy, No. 9, Physical and Mineralogical Methods, edited by: Klute, A., American Society of Agronomy/Soil Science Society, Madison, 1986.

Certini, G.: Effects of fire on properties of forest soils: a review, Oecologia, 143, 1-10, doi:10.1007/s00442-004-1788-8, 2005.

Chandler, C., Cheney, P., Thomas, P., Trabaud, L., and William, D.: Fire effects on soil, water and air, in: Fire in Forestry, Vol I: Forest fire behaviour and effects, John Wiley \& Sons, New York, 1983.

Dahlgren, R. A., Boettinger, J. L., Huntington, G. L., and Amundson, R. G.: Soil development along an elevational transect in the western Sierra Nevada, California, Geoderma, 78, 207-236, doi:10.1016/S0016-7061(97)00034-7, 1997.

DeBano, L. F.: The effect of fire on soil properties, in: Proceedings of the Symposium on Management and Productivity of WesternMontane Forest Soils, 10-12 April 1990, Boise, ID, 151-156, 1991.

DeBano, L. F.: The role of fire and soil heating on water repellency in wildland environments a review, J. Hydrol., 231, 195-206, doi:10.1016/S0022-1694(00)00194-3, 2000.

DeBano, L. F., Dunn, P. H., and Conrad, C. E.: Fire's effect on physical and chemical properties of Chaparral soils, in: Proceedings of the Symposium on the Environmental Consequences of Fire and Fuel Management in Mediterranean Ecosystems, 1-5 August 1977, Palo Alto, CA, 65-74, 1977.

DeBano, L. F., Neary, D. G., and Ffolliott, P. F.: Fire's effect on ecosystems, John Wiley \& Sons, Inc., New York, USA, 1998.

Diaz-Ravina, M., Prieto, A., Acea, M. J., and Carballas, T.: Fumigation extraction method to estimate microbial biomass in Heated Soils, Soil Biol. Biochem., 24, 259-264, doi:10.1016/00380717(92)90227-O, 1992.

FAO: State of the world's forest Food and Agricultural Organization of the United Nations, Rome, Italy, 2005.

Feller, C., Schouller, E., Thomas, F., Rouiller, J., and Herbillon, A. J.: $\mathrm{N}_{2}$-BET Specific surface areas of some low activity clay soils and their relationships with secondary constituents and organic matter contents, Soil Sci., 153, 293-299, doi:10.1097/00010694199204000-00005, 1992.

Fernández, I., Cabaneiro, A., and Carballas, T.: Organic matter changes immediately after a wildfire in an Atlantic forest soil and comparison with laboratory soil heating, Soil Biol. Biochem., 29, 1-1-1, doi:10.1016/S0038-0717(96)00289-1, 1997.

Fernández, I., Cabaneiro, A., and Carballas, T.: Thermal resistance to high temperatures of different organic fractions from soils under pine forests, Geoderma, 104, 281-298, doi:10.1016/S00167061(01)00086-6, 2001.

Frandsen, W. H. and Ryan, K. C.: Soil-Moisture Reduces Belowground Heat-Flux and Soil Temperatures under a Burning Fuel Pile, Can. J. Forest Res., 16, 244-248, 1986.

Giovannini, G.: The effect of fire on soil quality, in: Soil Erosion and Degradation as a Consequence of Forest Fires, edited by: Sala, M. and Rubio, J. L., Geoforma Ediciones, Logrono, 1994.

Giovannini, G., Lucchesi, S., and Giachetti, M.: Effect of heating on some physical and chemical parameters related to soil aggregation and erodibility, Soil Sci., 146, 255-261, doi:10.1097/00010694-198810000-00006, 1988. 
González-Pérez, J., González-Vila, F., Almendros, G., and Knicker, H.: The effect of fire on soil organic matter - a review, Environ. Int., 30, 855-870, doi:10.1016/j.envint.2004.02.003, 2004.

Harradine, F. and Jenny, H.: Influence of parent material and climate on texture and nitrogen and carbon contents of virgin California soils: texture and nitrogen contents of soils, Soil Sci., 85, 235243, 1958.

Harrison, S. P., Marlon, J. R., and Bartlein, P. J.: Fire in the Earth System, in: Changing Climates, Earth Systems and Society, edited by: Dodson, J., International Year of Planet Earth, Springer, New York, 2010.

Holden, S. R., Berhe, A. A., and Treseder, K. K.: Decreases in soil moisture and organic matter quality suppress microbial decomposition following a boreal forest fire, Soil Biol. Biochem., 87, 1-9, doi:10.1016/j.soilbio.2015.04.005, 2015.

Huntington, G. L.: The effect of vertical zonality on clay content in residual granitic soils of the Sierra Nevada mountains, University of California, Berkeley, 1954.

Janzen, C. and Tobin-Janzen, T.: Microbial communities in fireaffected soils, in: Microbiology of Extreme Soils, Soil Biology, 13, edited by: Dion, P. and Nautiyal, C. S., Springer-Verlag, Berlin, Heidelberg, 2008.

Jenny, H., Gessel, S. P., and Bingham, F. T.: Comparative study of decomposition rates of organic matter in temperate and tropical regions, Soil Sci., 68, 419-432, 1949.

Johnson, D. W., Susfalk, R. B., and Dahlgren, R. A.: Nutrient fluxes in forests of the eastern Sierra Nevada mountains, United States of America, Global Biogeochem. Cy., 11, 673681, doi:10.1029/97gb01750, 1997.

Johnson, D. W., Susfalk, R. B., Caldwell, T. G., Murphy, J. D., Miller, W. W., and Walker, R. F.: Fire Effects on Carbon and Nitrogen Budgets in Forests, Water Air Soil Poll., 4, 263-275, doi:10.1023/B:WAFO.0000028359.17442.d1, 2004.

Johnson, D. W., Murphy, J. D., Walker, R. F., Glass, D. W., and Miller, W. W.: Wildfire effects on forest carbon and nutrient budgets, Ecol. Eng., 31, 183-192, doi:10.1016/j.ecoleng.2007.03.003, 2007.

Kaiser, M., Kleber, M., and Berhe, A. A.: How air-drying and rewetting modify soil organic matter characteristics: An assessment to improve data interpretation and inference, Soil Biol. Biochem., 80, 324-340, doi:10.1016/j.soilbio.2014.10.018, 2015.

Ketterings, Q. M. and Bigham, J. M.: Soil color as an indicator of slash-and-burn fire severity and soil fertility in Sumatra, Indonesia, Soil Sci. Soc. Am. J., 64, 1826-1833, doi:10.2136/sssaj2000.6451826x, 2000.

Knicker, H.: How does fire affect the nature and stability of soil organic nitrogen and carbon? A review, Biogeochemistry, 85, 91118, doi:10.1007/s10533-007-9104-4, 2007.

Liang, B., Lehmann, J., Solomon, D., Kinyangi, J., Grossman, J., O’Neill, B., Skjemstad, J. O., Thies, J., Luizao, F. J., Petersen, J., and Neves, E. G.: Black carbon increases cation exchange capacity in soils, Soil Sci. Soc. Am. J., 70, 1719-1730, doi:10.2136/sssaj2005.0383, 2006.

Massman, W. J., Frank, J. M., and Mooney, S. J.: Advancing investigation and physical modeling of first-order fire effects on soils, Fire Ecol., 6, 36-54, doi:10.4996/fireecology.0601036, 2010.

Mataix-Solera, J., Cerda, A., Arcenegui, V., Jordan, A., and Zavala, L. M.: Fire effects on soil aggregation: a review, Earth-Sci. Rev., 109, 44-60, doi:10.1016/j.earscirev.2011.08.002, 2011.
McKelvey, K. S., Skinner, C. N., Chang, C.-R., Erman, D. C., Husari, S. J., Parsons, D. J., v. Wagtendonk, J. W., and Weatherspoon, C. P.: An overview of fire in the Sierra Nevada, University of California, Davis, California, 1996.

Munsell Color Science Laboratory, http://www.cis.rit.edu/research/ mcs12/online/munsell.php, last access: 9 June 2015.

National Interagency Fire Center: https://www.nifc.gov/fireInfo/ fireInfo_statistics.html, last access: 6 May 2015.

Neary, D. G., Klopatek, C. C., DeBano, L. F., and Ffolliott, P. F.: Fire effects on belowground sustainability a review and synthesis, Forest Ecol. Manage., 122, 51-71, doi:10.1016/S03781127(99)00032-8, 1999.

Nimmo, J. R. and Perkins, K. S.: Aggregate stability and size distribution, in: Methods of Soil Analysis, Part 4, Physical Methods, edited by: Dane, J. H. and Topp, G. C., Soil Science Society of America, Madison, Wisconsin, 2002.

Nishita, H. and Haug, R. M.: Some physical and chemical characteristics of heated soils, Soil Sci., 113, 422-430, doi:10.1097/00010694-197206000-00006, 1972.

Parsons, A., Robichaud, P. R., Lewis, S. A., Napper, C., and Clark, J.: Field guide for mapping post-fire soil burn severity, US Department of Agriculture, Forest Service, Rocky Mountain Research Station, Fort Collins, CO, 2010.

Pechony, O. and Shindell, D. T.: Driving forces of global wildfires over the past millennium and the forthcoming century, P. Natl. Acad. Sci. USA, 107, 19167-19170, doi:10.1073/pnas.1003669107, 2010.

Rasmussen, C., Matsuyama, N., Dahlgren, R. A., Southard, R. J., and Brauer, N.: Soil Genesis and Mineral Transformation Acrossan Environmental Gradient on Andesitic Lahar, Soil Sci. Soc. Am. J., 71, 225-237, doi:10.2136/sssaj2006.0100, 2007.

R Core Team: R: A Language and Environment for Statistical Computing, R Foundation for Statistical Computing, Vienna, Austria, 2014.

Rein, G., Cleaver, N., Ashton, C., Pironi, P., and Torero, J. L.: The severity of smouldering peat fires and damage to the forest soil, Catena, 74, 304-309, doi:10.1016/j.catena.2008.05.008, 2008.

Rible, J. M. and Quick, J.: Method S-19.0: Cation Exchange Capacity, in: Water, Soil, Plant Tissue: Tentative Methods of Analysis for Diagnostic Purposes, University of California Agricultural Experiment Service, Davis, CA, 1960.

Rietveld, H. M.: A Profile Refinement Method for Nuclear and Magnetic Structures, J. Appl. Crystallogr., 2, 65-71, doi:10.1107/S0021889869006558, 1969.

Rosa, J. M. D. 1., Gonzalez-Perez, J. A., Gonzalez-Vila, F. J., and Knicker, H.: Medium term effects of fire induced soil organic matter alterations on Andosols under Canarian pine (Pinus canariensis), J. Anal. Appl. Pyrol., 104, 269-279, doi:10.1016/j.jaap.2013.07.006, 2013.

Rossel, R. A. V., Minasny, B., Roudier, P., and McBratney, A. B.: Colour space models for soil science, Geoderma, 133, 320-337, doi:10.1016/j.geoderma.2005.07.017, 2006.

Schulze, D. G. and Dixon, J. B.: An introduction to soil mineralogy, in: Soil mineralogy with environmental applications, edited by: Schulze, D. G. and Dixon, J. B., Soil Science Society of America, Inc., Madison, Wisconsine, USA, 2002.

Six, J., Elliott, E. T., and Paustian, K.: Soil macroaggregate turnover and microaggregate formation: a mechanism for $\mathrm{C}$ sequestration 
under no-tillage agriculture, Soil Biol. Biochem., 32, 2099-2103, doi:10.1016/S0038-0717(00)00179-6, 2000.

Skinner, C. N. and Chang, C.-R.: Fire Regimes, Past and Present, in: Sierra Nevada Ecosystem Project, Final Report to Congress, Vol. II, Assessment and Scientific Basis for management Options, University of California, Center for Wate rand Wildland Resoures, Davis, 1996.

Soto, B. and Diazfierros, F.: Interactions between plant ash leachates and soil, Int. J Wildland Fire, 3, 207-216, doi:10.1071/Wf9930207, 1993.

Soto, B., Benito, E., Basanta, R., and Díaz-Fierros, F.: Influence of antecedent soil moisture on pedological effects of fire, in: Soil Erosion and Degradation as a Consequence of Forest Fires, edited by: Sala, M. and Rubio, J. L., Geoforma Ed., Logroño, Spain, 1991.

Sparks, D. L.: Environmental Soil Chemistry, 2 Edn., Elsevier Academic Press, San Diego, CA, 2003.

Stacy, E. M., Hart, S. C., Hunsaker, C. T., Johnson, D. W., and Berhe, A. A.: Soil carbon and nitrogen erosion in forested catchments: implications for erosion-induced terrestrial carbon sequestration, Biogeosciences, 12, 4861-4874, doi:10.5194/bg-124861-2015, 2015.

Tas, N., Prestat, E., McFarland, J. W., Wickland, K. P., Knight, R., Berhe, A. A., Jorgenson, T., Waldrop, M. P., and Jansson, J. K.: Impact of fire on active layer and permafrost microbial communities and metagenomes in an upland Alaskan boreal forest, ISME J., 8, 1904-1919, doi:10.1038/ismej.2014.36, 2014.

Terefe, T., Mariscal-Sancho, I., Peregrina, F., and Espejo, R.: Influence of heating on various properties of six Mediterranean soils: a laboratory study, Geoderma, 143, 273-280, doi:10.1016/j.geoderma.2007.11.018, 2008.

Thomas, G. W.: Soil pH and soil acidity, in: Methods of Soil Analysis, Part 3, Chemical Methods, edited by: Sparks, D. L., Page, A. L., Helmke, P. A., and Loeppert, R. H., Soil Science Society of America/American Society of Agronomy, Madison, Wisconsin, 1996.

Trumbore, S., Chadwick, O., and Amundson, R.: Rapid exchange between soil carbon and atmospheric carbon dioxide driven by temperature change, Science, 272, 393-396, doi:10.1126/science.272.5260.393, 1996.
Ubeda, X. and Outeiro, L. R.: Physical and Chemical Effects of Fire on Soil, in: Fire Effects on Soils and Restoration Strategies, edited by: Cerda, A. and Robichaud, P. R., Land Reconstruction and Management, Science Publishers, Enfield, NH, USA, 2009.

UC Davis Soil Resource Laboratory: http: //casoilresource.lawr.ucdavis.edu/software/ r-advanced-statistical-package/color-functions/ convert-munsell-colors-computer-friendly-rgb-triplets/2015, last access: 9 June 2015.

Ulery, A. L. and Graham, R. C.: Forest-fire effects on soil color and texture, Soil Sci. Soc. Am. J., 57, 135-140, doi:10.2136/sssaj1993.03615995005700010026x, 1993.

Ulery, A. L., Graham, R. C., and Amrhein, C.: Wood-Ash Composition and Soil-pH Following Intense Burning, Soil Sci., 156, 358-364, doi:10.1097/00010694-199311000-00008, 1993.

US Geological Survey: USGS NED and $1: 1,000,000-$ Scale Contours, USGS, Reston, VA, 2015.

van Wagtendonk, J. W. and Fites-Kaufman, J. A.: Sierra Nevada Bioregion, in: Fire in California's Ecosystems, edited by: Sugihara, N. G., van Wagtendonk, J. W., Shaffer, K. E., and Thode, A. E., University of California Press, Berkeley, CA, USA, 2006.

Varela, M. E., Benito, E., and Keizer, J. J.: Effects of wildfire and laboratory heating on soil aggregate stability of pine forests in Galicia: the role of lithology, soil organic matter content and water repellency, Catena, 83, 127-134, doi:10.1016/j.catena.2010.08.001, 2010.

Westerling, A. L., Hidalgo, H. G., Cayan, D. R., and Swetnam, T. W.: Warming and earlier spring increase western U.S. forest wildfire activity, Science, 313, 940-943, doi:10.1126/science.1128834, 2006.

Zavala, L. M., Granged, A. J. P., Jordán, A., and Bárcenas-Moreno, G.: Effect of burning temperature on water repellency and aggregate stability in forest soils under laboratory conditions, Geoderma, 158, 366-374, doi:10.1016/j.geoderma.2010.06.004, 2010. 